\title{
Andróginos y ciborgs: monstruos de deconstrucción
}

\author{
Androgyous and cyborgs: deconstruction monsters
}

\begin{abstract}
ANA SÁNCHEZ ANGUIX
Universitat de València • asanan4@alumni.uv.es

Graduada en Estudios Hispánicos, realiza una investigación sobre las representaciones

problemáticas de la sexualidad y las construcciones de género.
\end{abstract}

RECIBIDO: 9 DE JULIO DE 2015

ACEPTADO: 23 DE JULIO DE 2015

Resumen: En nuestro corpus, conformado por obras literarias y cinematográficas, los cuerpos monstruosos del ciborg y del andrógino devienen seres fronterizos que cuestionan los parámetros de sexo, género y deseo. Lo humano es puesto en duda y lo invisible se vuelve visible, abriendo un amplio espectro en la naturaleza. En el presente estudio se examinan las figuras del andrógino y del ciborg a la luz de las teorías de género: por un lado, se estudia el lugar de ambos monstruos en el feminismo deconstructivista; por otro, desde la perspectiva queer, ambos puntos de vista vinculados. Para nuestro análisis se tendrán en cuenta conceptos como género/sexo, dualidad sexual, intersexualidad o (hetero)patriarcado.

Palabras Clave: Piglia, detective, investigación, crimen, ley, periodismo, sexualidad, ficción paranoica.

\begin{abstract}
In the works here analyzed -literary as well as filmic discourses- cyborg and androgyne monstrous bodies become frontier beings which question sex, gender and desire patterns. What is human is also questioned, and the invisible turns into visible, thus widening our notion of the natural. In the present study, androgyne and cyborg are examined from a gender perspective: on the one hand, these monsters are taken into account from feminist deconstruction view; on the other hand, we will go back to our works analyzing them from the queer theory perspective. Both feminism and queer theory are, though, related to each other. Throughout our whole study, we will consider terms such as gender/sex, sexual duality, intersex or (hetero)patriarchy.
\end{abstract}

Key Words: androgyny, cyborg, gender, feminism, queer.

DOI: 10.7203/KAM.5.6465 
Ana Sánchez Anguix. Andróginos y ciborgs...

\section{Introducción}

Cuerpos abyectos, al margen de los patrones de belleza, femineidad, masculinidad, humanidad. Asentado el periodo moderno, los cuerpos se mecanizan y degeneran, y el arte, de algún modo, atrapa entre la luz y la penumbra la fractura de esos cuerpos (v. Pedraza, 1984: 185-198). Son mutilados, convertidos en desecho, en muñecas de cera o en maniquíes.

La mujer se convierte en un ser inerte, muchas veces sin rostro. En algunas de las Estampas de Máquinas y Maniquíes de Maruja Mallo, las mujeres fuertes y atléticas de las Estampas deportivas dejan paso a cuerpos mutilados, vacíos y rodeados de un espacio urbano en efervescencia; son simples maniquíes (Barrera, 2014: 237 y 238). También los cuerpos ambivalentes comienzan a plasmarse sobre lienzo. En Frida Kahlo se observa un uso del vestido que oculta y a un mismo tiempo escenifica la abyección de su propio cuerpo; así descubre y anula su feminidad, representándolo como disfraz o como máscara (Girona, 2008: 199 y 200). Es un andrógino.

Cuerpos monstruosos, cuerpos en los límites.

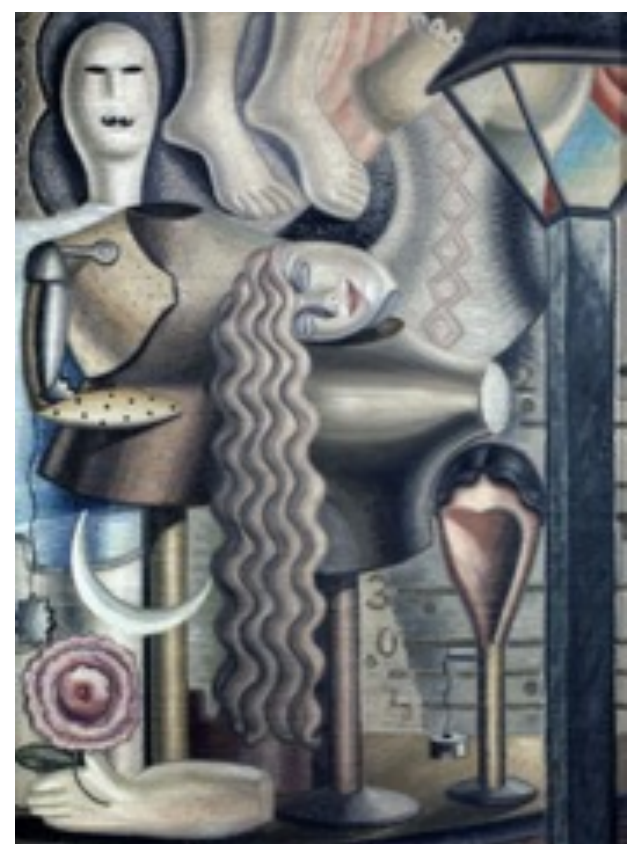

Estampa urbana (1928)

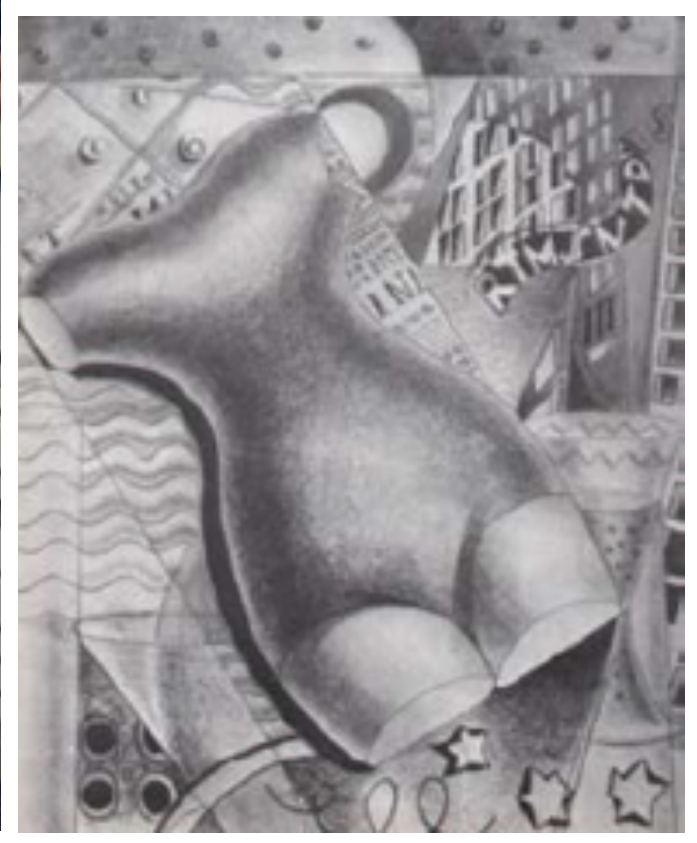

Estampa (1928)

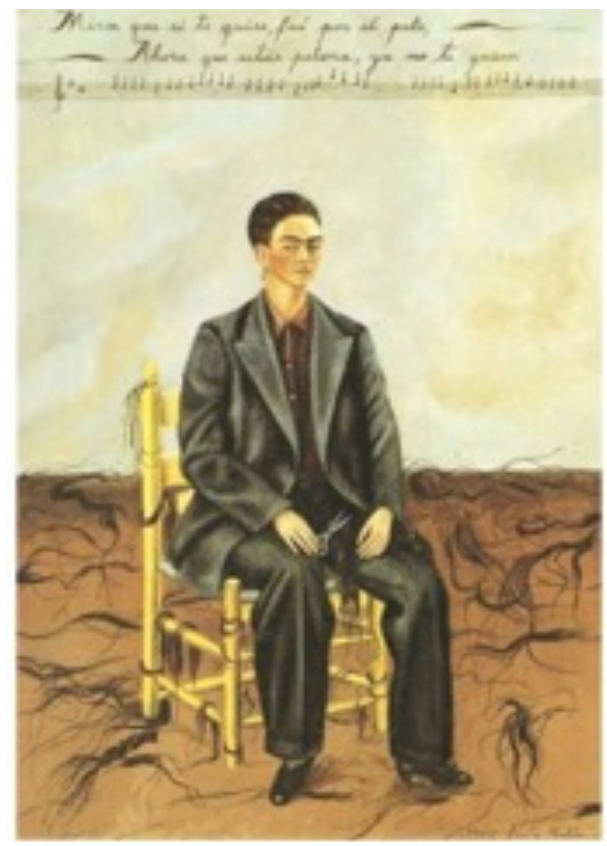

Autorretrato con el pelo corto (1940) 
Ana Sánchez Anguix. Andróginos y ciborgs...

¿En qué modo lo abyecto deviene un arma contra los cánones? ¿En qué modo la literatura y el cine han tratado de desplazar las dicotomías que rigen el pensamiento de Occidente por medio de estos cuerpos? En algunos textos y filmes de este estudio, la androginia y el ciborg son seres centáuricos, fronterizos, que desafían la dualidad sexual y redefinen los parámetros del deseo; son monstruos de deconstrucción porque, lejos de dejar el paisaje en ruinas, crean su propio espacio de debate. Veamos cómo.

\section{El andrógino}

1.1 La androginia en los feminismos

No creo que la mujer deba de ser el sujeto político del feminismo, Beatriz Preciado

¿De qué sujetos, de qué cuerpos, deberían ocuparse la teoría y actividad feministas? Preciado (2014a) apunta a la desidentificación de las llamadas ficciones políticas, que abrazan nociones de masculinidad/feminidad, heterosexualidad/homosexualidad, normali-dad/patología. La androginia guarda estrecha relación con los debates feministas en torno a la definición de la mujer y el cuerpo y sexualidad femeninas: mientras que algunas propuestas se decantan por la exaltación de unos valores y cultura propios del sexo femenino (el feminismo cultural y el de la diferencia), otras autoras se posicionan en contra de la limitación del concepto de mujer y optan más bien por la deconstrucción de las categorías genéricas o sexuales.

Tanto el feminismo cultural (en EE. UU.) como el feminismo de la diferencia (en Francia e Italia) ejercieron una fuerte crítica hacia los valores masculinos: mientras la mujer tiene una sexualidad tierna, difusa y es dulce y maternal (y está asociada, pues, a la naturaleza ${ }^{1}$, a la creación), el hombre ejerce sobre la mujer una sexualidad violenta, y está ligado a la cultura (Osborne, 2005: 217). Aunque estas

\footnotetext{
${ }^{1}$ Resulta de interés el análisis que se hace en algunas teorías ecofeministas de la relación entre la naturaleza y la mujer: si en la tradición occidental se había establecido una asociación entre la mujer y la naturaleza como organismos pródigos primero y mecánicos e inertes después de la Revolución Industrial, la conquista y dominación de la naturaleza supuso también la subyugación de la mujer (Aguilar, 2008: 115). Veremos cómo esa identificación de lo femenino con lo mecánico se realizará también a través de la figura del autómata, imagen femenina que se inten-tará derrocar desde presupuestos, no ecofeministas, sino ciberfeministas. A diferencia del ecofeminismo, la teoría de Haraway y el ciberfeminismo verán la tecnología como una herramienta liberadora de la mujer (Aguilar, 2008: 116).
} 
Ana Sánchez Anguix. Andróginos y ciborgs...

corrientes feministas sometían a un juicio crítico la ideología burguesa, en el primer caso $^{2}$, y las políticas sobre la reproducción femenina llevadas a cabo por los poderes masculinos, en el del feminismo de la diferencia $^{3}$, otras autoras feministas encontraron en estas teorías la cristalización de los valores patriarcales y de la diferencia sexual.

Frente a este discurso esencialista, otras autoras plantearán la deconstrucción de la identidad, y en particular de la identidad de género. Alcoff, que revisa en su artículo este debate en torno a la esencialidad de la mujer, afirma que cualquier intento de definición de la feminidad se halla condicionado por los valores patriarcales, que se oponen a lo otro y han sentado una cultura «construida sobre el sometimiento de las mujeres» (2002: 18; idea que también aparece en Osborne, 2005: 233, y Lauretis, 1989: 2). Los discursos «esencialistas» crean, además, la ilusión de que la identidad femenina «es innata, en lugar de socialmente construida» (Alcoff, 2002: 22; véase asimismo Osborne, 2005: 225). En este sentido, Judith Butler critica la asunción de una teoría feminista que gire alrededor de la dicotomía masculino/femenino y que deje de lado la construcción de otras categorías igual-mente opresoras: etnia, clase, etc. (Osborne, 2005: 224; también en Lauretis, 1989: 2).

Más allá del feminismo, pero partiendo de él, se encuentra la teoría queer, que se centra en la exclusión y denigración que han sufrido los colectivos homosexuales, de transexuales y de travestis, los cuales «han traspasado las barreras del género que responden a los pares tradicionales hombre/mujermasculino/femenino» (Osborne, 2005: 243 y 244). Otro de los puntos centrales de la teoría queer será precisamente la movilidad del deseo y la inestabilidad de la sexualidad y del género (Osborne, 2005: 244). Por eso llama la atención el hecho de que algunas teóricas del feminismo cultural vean en la transexualidad una apropiación de lo femenino por parte de los hombres:

\footnotetext{
${ }^{2}$ En efecto, el feminismo radical de los años 60 , del que bebe ese otro feminismo cultural de las décadas de los 70 y de los 80 , había surgido como reacción a la sociedad burguesa que asignaba al hombre y a la mujer distintos ro-les: mientras el primero se movía en el terreno político, público, la segunda quedaba confinada al ámbito privado, a las cuatro paredes del hogar, en que debía ocuparse de la crianza de la prole, tarea asociada a la reproducción, frente a la sexualidad masculina; lo que hará el feminismo radical será ligar las esferas públicas y privadas en la conocida fórmula de Kate Millet: «lo personal es lo político» (Osborne, 2005: 213-215).

${ }^{3}$ El feminismo de la diferencia europeo, con autoras como Luce Irigaray en Francia o Luisa Muraro en Italia, here-da, a su vez, los presupuestos del feminismo cultural estadounidense, pero oponiéndolos a un primer feminismo de la igualdad de bases ilustradas que destacaba la noción de género como construcción social (Posada, 2005: 294 y 295). En el caso del feminismo de la diferencia sexual italiano, las feministas buscaban además lo que Muraro llamó la «madre simbólica», un conjunto de referencias filosóficas y literarias que intentaban conformar una cultu-ra femenina propia que escapase de esos valores masculinos integradores del poder político (Posada, 2005: 302-306). Aquí se apunta, de nuevo, a la maternidad, estigma patriarcal de la mujer (Posada, 2005: 312 y 313 ).
} 
Ana Sánchez Anguix. Andróginos y ciborgs...

Siempre había pensado que el fenómeno del transexualismo (así como el del hermafroditismo, e incluso el del travestismo) resultaba relevante para cuestionar la fundamentación biológica de los roles sexuales así como para, a la vez, mostrar la fuerza de dichos roles, que obligaban a tantos seres a sentirse incómodos con su cuerpo (Osborne, 2005: 234; la cursiva es nuestra).

En esta última cita, hemos subrayado las palabras hermafroditismo y travestismo. En algunos textos se presentan como formas de deconstrucción de género, y ambas pueden relacionarse en mayor o menor medida con la androginia antes apuntada. Para nosotros, la androginia será una práctica deconstructiva del género que tratará de poner en duda las categorías heteronormativas; por tanto, podrá enfocarse tanto desde un punto de vista feminista como queer. Frente al feminismo cultural (o el de la diferencia), la deconstrucción de género tiene en cuenta la falta de una esencialidad en el sujeto, lo cual da «rienda suelta a una pluralidad de diferencias» (Alcoff, 2002: $26)^{4}$.

El feminismo deconstructivista de Lauretis resulta muy interesante para plantear la figura del andrógino. Esta autora ve en la deconstrucción una vía para un nuevo feminismo, que se alejará de las corrientes esencialistas y que tratará de descubrir las llamadas tecnologías del género, partiendo de la teoría foucaultiana sobre la sexualidad y del pensamiento marxista de Althusser (v. Lauretis, 1989) ${ }^{5}$. El género sería no una propiedad inherente a los cuerpos, sino los efectos que en estos provocan los aparatos ideológicos del Estado, los cuales pueden abarcar desde los productos artísticos y culturales hasta el propio feminismo (Lauretis, 1989: 8 y 9). El género confiere una identidad, del mismo modo que adquiere el individuo una conciencia de clase; se basa en la forma en que nos relacionamos con el resto de individuos según el sexo biológico que se nos asignó al nacer: el género es la causa y el efecto de su representación y de su auto-representación (Lauretis, 1989, 10, 11 y 15).

\footnotetext{
${ }^{4}$ A esta misma idea apunta Judith Butler $(2002,55)$ : «la categoría de mujeres no se vuelve inútil mediante la deconstrucción», lo que quiere decir que no se desvanece la identidad, pregunta que se hace también Alcoff (2002). Por el contrario, continúa Butler $(2002,55)$ «se convierte en una categoría cuyos usos ya no se reifican como "refe-rentes" y que presenta la oportunidad de que se la abra (...), de llegar a significar de maneras que ninguno de noso-tros puede predecir de antemano».

5 No obstante, Lauretis se opone al marxismo tradicional cuando este hace del problema de género una cuestión exclusivamente femenina, asentando la diferenciación que anteriormente señalamos entre el ámbito público y pri-vado, y cayendo, pues, en los propios parámetros de la ideología burguesa (Lauretis, 1989: 12). La teoría de Althusser, que explora la función de la ideología no solo en el sistema socioeconómico sino en la subjetividad del individuo, puede funcionar, sin embargo, como tecnología de género; en este sentido, Lauretis cita a Michèle Barret, quien da la vuelta a la relación del sistema capitalista con el género: la construcción del género ha influido también en la división del trabajo y en otras relaciones de producción (1989: 13).
} 
Ana Sánchez Anguix. Andróginos y ciborgs...

La crítica que Lauretis hace a la propia teoría feminista pretende buscar un nuevo modelo para el movimiento; el feminismo se halla, no fuera de la ideología, sino imbricada en ella (no se adhiere, explica, es cómplice) (Lauretis, 1989: 16 y 17). ¿De dónde partir, entonces, para la deconstrucción del género y de las relaciones sociales que lo perpetúan? ¿Podría ser uno de esos lugares el andrógino, o el ciborg, como planteará Haraway? La ambigüedad del género se ofrece, a sus ojos, como una buena alternativa:

(...) podemos mantener la esperanza de que el feminismo seguirá desarrollando una teoría radical y una práctica de transformación sociocultural. Para que ello ocurra, sin embargo, debe retenerse la ambigüedad de género (...). No podemos resolver o disipar la incómoda condición de estar al mismo tiempo dentro y fuera del género, o bien por desexualizarlo (...) o por androginizarlo ${ }^{6}(\ldots)$ (Lauretis, 1989: 18; la cursiva es nuestra).

\subsection{La figura del andrógino y la teoría del andrógino en Virginia Woolf}

El mito del andrógino se remonta a la filosofía de Platón, el primer autor que hace constar la existencia en el imaginario occidental de un ser que comparte características de ambos sexos ${ }^{7}$. De la descripción que se hace del andrógino nos interesa subrayar su condición monstruosa (Vásquez, 2001: 181), que, como veremos, lo caracterizará como un ser apartado de los cánones, y, por tanto, como transgresor $^{8}$. Es evidente que en El banquete el andrógino no sirve sino como explicación mitológica de un comportamiento humano que, eso sí, acepta la homosexualidad masculina; es más, encontramos en la

\footnotetext{
${ }^{6}$ Fijémonos en que aquí la autora plantea el término en el sentido de alegar «la misma experiencia de condiciones materiales para ambos sexos en una clase, raza o cultura determinada» (Lauretis, 1989: 18). Se entendería aquí por andrógino la fusión de ambos sexos, no como ambigüedad de género, no como una subjetividad que permanece en las fronteras entre lo tradicionalmente masculino y lo tradicionalmente femenino, que es el sentido que nosotros manejamos para la figura del andrógino.

${ }^{7}$ En El banquete, una reflexión en forma dialógica acerca de la naturaleza del amor, uno de los personajes, Aristófanes, se refiere al mito del andrógino: antes existían tres sexos, los hombres, las mujeres y los andróginos. Estos últimos osaron ascender al cielo para atacar a los dioses, de ahí que Zeus decidiera, como castigo, separar las dos mitades, la masculina y la femenina, que llegarán a dedicar toda una vida para encontrarse y fundirse en el abrazo (Platón, 2012: 79-88).

${ }^{8}$ Explica Aristófanes en este pasaje: «la figura de cada individuo era por completo esférica (...); tenía cuatro brazos e igual número de piernas que de brazos, y dos rostros sobre un cuello circular (...); y una cabeza, una sola, sobre estos dos rostros, situados en direcciones opuestas, y también cuatro orejas, dos órganos sexuales y todo lo demás según puede uno imaginarse de acuerdo con lo descrito hasta aquí» (Platón, 2012: 81).
} 
reflexión de Aristófanes una marcada diferenciación entre mujeres y hombres, asignándoles a cada uno un origen distinto (la primera es proveniente de la tierra, el segundo, del sol, el andrógino, de la luna) ${ }^{9}$.

En las antípodas del discurso platónico, algunas teorías feministas retoman la figura del andrógino como deconstrucción de género. Esta categoría, que en filósofas como Beauvoir constituía un constructo social y discursivo, ha pasado a equivaler para otras a la categoría de sexo (Butler, 2002: 17). Para Judith Butler, este funciona como una práctica que controla y normaliza los cuerpos, mientras que degrada otros a lo abyecto $(2002: 18,20)^{10}$. En este punto, el andrógino puede entenderse como esa figura capaz de poner en duda, no solo el género, sino también la diferencia sexual. De cómo esta diferenciación de los sexos se traslada de lo biológico al discurso darán cuenta precisamente los textos de nuestro corpus, pues el sexo acaba siendo «una postulación, una construcción, ofrecida dentro del lenguaje, como aquello que es anterior al lenguaje, anterior a la construcción» y es, pues, «una fantasía» (Butler, 2002: 23). Con Bodies that matter, juego de palabras que da nombre a su ensayo, Butler $(2002,60)$ pone el acento sobre la importancia del lenguaje, de la materia, para legitimar unos cuerpos en detrimento de otros.

El cuerpo se convierte en un ente textual, en un discurso que compone y se halla compuesto de otros discursos (Butler, 2002: 110 y 111), ya que «no hay ninguna referencia a un cuerpo puro que no sea al mismo tiempo una formación adicional de ese cuerpo» (Butler, 2002: 31 y 32). El cuerpo es una materia, pero esta es siempre, desde un punto de vista etimológico, algo temporalizado, no está exento de significación (Butler, 2002: 58 y 59). Volver a la materialidad del cuerpo, según Butler (2002, 87), puede dar cuenta de la historia de la construcción y jerarquía de estos cuerpos, de la materia «como un signo que, con sus resonancias y contradicciones, representa un drama incompleto de la diferencia sexual». El cuerpo abyecto es aquel contrario a los parámetros de la belleza y del sexo, como lo serán los andróginos y los ciborgs ${ }^{11}$.

\footnotetext{
${ }^{9}$ Asimismo, se menciona la concepción del andrógino en la polis griega: «el andrógino (...) ahora no es sino un nombre que yace en la ignominia». En una nota al pie de página, Fernando García Romero explica que en algunos autores coetáneos a Platón, andrógino aludía a un «hombre afeminado y cobarde» y, en femenino, a una «mujer corrupta» (2012, 81). Lo monstruoso del andrógino devendrá con el feminismo y las teorías queer, como veremos, en un otro resistente a los moldes heteropatriarcales.

${ }^{10}$ Según esta autora (Butler, 2002: 22 y 23), el sexo opera en tanto que es una noción natural, biológica, que sin embargo se construye socialmente. Es en este sentido en el que Butler habla de la disolución de la diferencia entre el sexo y el género. Preciado (2014a) habla también de la abyección a la que se somete el cuerpo femenino en los tratados médicos de los siglos XVI y XVII, donde es concebido como una deformación del cuerpo masculino, y en los de los siglos XVIII y XIX, donde el discurso científico está al servicio de la opresión de la mujer.

11 Para un relación entre belleza y abyección, v. Solorza (2009), a propósito también del cuento de Silvina Ocampo Las vestiduras peligrosas.
} 
Ana Sánchez Anguix. Andróginos y ciborgs...

La diferenciación sexual da forma o materializa el binarismo de los cuerpos masculino y femenino, pero también, en las sombras, la existencia de lo que se aparta de ello, de lo abyecto (Butler, 2002: 90). Es, pues, lógico, que algunas de las corrientes feministas adopten la actitud andrógina como una estrategia subversiva con la que derribar las restricciones a las que someten el género y el sexo asignado al nacer ${ }^{12}$. A esta actitud andrógina, puesta en relación con las teorías queer, que abordaremos más adelante, se le llama también gender-queer, término que hace referencia a la deconstrucción del género (Villar, 2015). En algunas ficciones de los siglos XX y XXI, esta androginia se plasma en forma de personas con inter-sexualidad, entre las que se prefiere el segundo término ${ }^{13}$.

Pero el andrógino, como advierte Vásquez, va más allá tanto del mito platónico como del hermafrodita tal y como se concibe en el imaginario popular, ya que es «un cuerpo situado en el territorio de la ambigüedad, escapando de las redes convencionales de la representación de los cuerpos y de su deseo» $(1998,976)$. El andrógino puede encontrarse en el intersexual de algunas ficciones (la novela norteamericana Middlesex o el film argentino $X X Y$ ), en el travestismo de algunos personajes femeninos (como en los cuentos de Angélica Gorodischer), en algunos grupos musicales (Kiss, Queen) ${ }^{14}$ o en personajes fantásticos que cambian su sexo inconsciente y conscientemente (como el/la protagonista de Orlando y de Las joyas de la serpiente, respectivamente).

Entre los textos de nuestro corpus consideramos pioneros una de las novelas más comentadas desde las perspectivas feminista y queer, Orlando, y uno de los primeros ensayos considerados feministas e igualmente objeto de estudio y de polémica, Una habitación propia, ambos de la escritora británica

12 En El género en disputa, Butler aborda precisamente las prácticas discursivas y performativas capaces de transgredir los valores del género en la estructura patriarcal (v. Butler, 2007, 7-33). La performatividad en Butler cobra suma importancia puesto que el género se construye (y deconstruye) a partir de «un conjunto sostenido de actos» (Butler, 2007: 17). Así, uno de los principales objetivos de esta autora será el de rescatar los cuerpos y sexualidades que escapen de la heteronorma (2007, 24), lo que retomaremos al hablar de $X X Y$. Para Lauretis, serán, en cambio, los «espacios en los márgenes en el discurso hegemónico», «las grietas y resquebrajaduras de los aparatos del poder-saber» lo que permitirá deconstruir el género (1989, 33). Ambas apuntan a una idea similar: mientras que Butler se centra en la performatividad, que también, recordemos, se halla en el lenguaje (v. gr. en la teoría de los actos de habla de Austin y Searle), Lauretis parece señalar una noción más general, aludiendo a esos espacios.

13 Para un estudio desde la perspectiva feminista, además, la androginia, aunque no equivalente de la intersexualidad y del hermafroditismo, se prefiere a este último concepto, que se aproxima más a lo masculino, al que se añadiría el elemento femenino; la androginia, sin embargo, se liga a la «indefinición, una frontera desconcertante donde el cariz y lo que se desprende de ella es aparentemente independiente de la ostentación de un sexo doble» (Vásquez, 2001: 182), lo cual casa con la ambigüedad que preconizaba Lauretis.

${ }^{14}$ La androginia en la cultura popular se halla ligada muy frecuentemente a la estética camp y a lo queer. Para un estudio de estas relaciones en las prácticas culturales hispanoamericanas, v. Hueso (2012). Se encontrarán también ejemplos de ello en Vásquez (1998:973-977). 
Virginia Woolf. En esta última obra, la autora plantea la necesidad de independencia económica para la artista y señala, de paso, una poética contraria a la que propondrían autoras como Cixous para la escritura femenina. Aunque algunos autores y autoras han señalado un feminismo de carácter esencialista en el ensayo de Woolf, este se enfoca aquí desde el deconstructivismo. Fuster (2010) recoge múltiples lecturas que vinculan el texto de Woolf al feminismo de la diferencia sexual: la crítica a la descripción de las mujeres en relación con los hombres (como «espejos dotados del mágico y delicioso poder de reflejar una silueta del hombre del doble del tamaño natural»; Woolf, 2001: 50) y la defensa de una diferenciación clara entre los sexos (Fuster, 2010: 221).

En este sentido, para Fuster (2010: 223, 225), la androginia de la que habla Woolf no se aplica al ámbito político, sino únicamente al de la escritura, principal objeto de reflexión de la autora ${ }^{15}$. No obstante, veremos cómo en Orlando, novela que se ha vinculado con frecuencia a las tesis de Una habitación propia (Gascón Vera, 2002: 105), se establece una estrecha relación entre la condición sexual o de género (que atañe al ámbito político y a la conducta en sociedad) y la escritura, dos ámbitos diferenciados por Fuster. Es más, en el mismo ensayo publicado por Woolf en 1929, observamos no solo cuestiones referentes al ámbito artístico, literario, sino también al político, ya sea con la crítica que Woolf hace del fascismo (Woolf, 2001: 139) o de la opresión de la mujer a lo largo de la historia, ya con la necesidad para la escritora de ser independiente económicamente, tesis referida a través de la famosa imagen de la habitación propia ${ }^{16}$.

Desde el feminismo deconstructivista es desde donde, en nuestra opinión, puede leerse la androginia de Woolf. Ya en las primeras páginas la autora parece no querer caer en esencialismos, cuando desmiente que el objetivo de su ensayo sea el de describir «las mujeres y su modo de ser; o las mujeres y las novelas que escriben; o las mujeres y las fantasías que se han escrito sobre ellas» (Woolf, 2001: 9). Asimismo, la autora recoge citas de manuales misóginos del British Museum, el cual considera como «un departamento más de la fábrica» que es Londres (Woolf, 2001: 38); esta afirmación recordará

\footnotetext{
${ }^{15}$ Gascón-Vera (2002: 102), por el contrario, afirma que se establece un «paralelismo entre controlar el espacio de escribir y el espacio de ser mujer con posibilidad de elección», esto es, la actividad literaria y el contexto social, político, están, para Woolf, estrechamente unidos. No obstante, parece coincidir con Fuster cuando señala que Woolf acaba reafirmando las diferencias entre hombres y mujeres, eso sí, en defensa de múltiples posibilidades sexuales, genéricas y, por tanto, desestructurando la dicotomía masculino-femenino (2002: 108). En este punto coincide con Wright (2006: 12): «Difference is to be celebrated, but should exist within the individual androgynous self-fertilising mind».

${ }^{16}$ Esta asociación entre lo político y lo literario se lleva a otra metáfora igualmente poderosa: «la obra de imaginación es como una tela de araña: está atada a la realidad, leve, muy levemente quizá, pero está atada a ella por las cuatro puntas. (...) Estas telas de araña no las hilan en el aire criaturas incorpóreas, sino que son obra de seres humanos que sufren y están ligadas a las cosas groseramente materiales, como la salud, el dinero y las casas en que vivimos» (Woolf, 2001: 60).
} 
Ana Sánchez Anguix. Andróginos y ciborgs...

a las «tecnologías del género» según Lauretis, lectura que se confirma cuando leemos: «Inglaterra se hallaba bajo un patriarcado» (Woolf, 2001: 48) ${ }^{17}$.

Otro de los puntos en los que es posible una lectura deconstructivista del ensayo de Woolf es la crítica que hace a la exaltación de los valores femeninos de un modo similar a como se ha estado haciendo con los masculinos. Es esta una de las trampas en las que caerían el feminismo cultural y el de la diferencia; Woolf, después de marcar una diferencia entre las novelas masculinas y las femeninas (Woolf, 2001: 107), afirma: «Pero, ay de mí, había hecho lo que estaba decidida a no hacer: había caído sin pensar en la alabanza de mi propio sexo (...) y el alabar el propio sexo es siempre sospechoso y a menudo tonto» (Woolf, 2001: 117).

La androginia de Woolf se concibe como una actitud del artista, sí, pero estrechamente vinculada con la presión social ejercida sobre el pensamiento y el cuerpo: «¿Por qué siento que hay discordias y oposiciones en la mente, de igual modo que hay en el cuerpo tensiones producidas por causas evidentes?» (Woolf, 2001: 131); "son culpables todos los que han contribuido a despertar conciencia del sexo y son ellos quienes me empujan (...) a buscar satisfacción en aquella época feliz (...) en que el escritor utilizaba ambos lados de su mente a la vez» (Woolf, 2001: 140) ${ }^{18}$. Con esta actitud en la actividad (performativa, diría Butler) de la literatura, una logra así olvidarse de su sexo; porque «no debe haber obstáculos en ella [la mente], ningún cuerpo extraño inconsumido» (Woolf, 2001: 79). La mente

${ }^{17}$ La imagen del espejo de la que hablábamos también puede reinterpretarse desde aquí, ya que Woolf, al referirse a la descripción de las características psíquicas de la mujer por parte de científicos consagrados, señala el temor narcisista de estos «patriarcas»: «cuando el profesor insistía con demasiado énfasis sobre la inferioridad de las mujeres, no era la inferioridad de estas lo que le preocupaba, sino su propia superioridad» (2001: 49), y continúa: «las mujeres no pueden decir este libro es malo, este cuadro es flojo o lo que sea sin causar mucho más dolor y provocar mucha más cólera de los que causaría y provocaría un hombre que hiciera la misma crítica (...) si ellas se ponen a decir la verdad, la imagen del espejo se encoge; la robustez del hombre ante la vida disminuye» (Woolf, 2001: 51).

18 Algunos autores (Wright, 2006: 2 y 3; Rognstad, 2012: 5, 28) también han señalado la posible influencia del Bloomsbury Group, un ambiente intelectual abierto a la sexualidad y a las recientes teorías del psicoanálisis. Para algunos psicoanalistas, la homosexualidad y la bisexualidad respondían a una ambigüedad sexual que se resolvía de un modo aberrante, monstruoso. La apropiación por parte de Woolf de esta ambigüedad abyecta tanto en sus textos como en su propia biografía para expresar un ansia de libertad creativa y sexual es otro factor que acerca el concepto de Woolf a nuestra androginia. Al inicio del cuarto capítulo Woolf habla de cómo a algunas escritoras se las ha caracterizado como «monstruo», lo cual enlaza con la condición teratológica de que ya hablamos. 
Ana Sánchez Anguix. Andróginos y ciborgs...

andrógina, que Woolf parece concebir en principio como la unión entre los dos sexos, permanece finalmente en la ambigüedad ${ }^{19}$.

Aunque las teorías de Woolf y de Butler difieren claramente, parece haber algo en común: la primera ya supo percibir que el cuerpo, el sexo que se nos asigna, constriñe la actividad literaria, debido a los múltiples escollos que debía superar toda escritora (prejuicios de críticos literarios, la restricción moral de la época). La deconstrucción del género en Woolf se leería en clave metaliteraria, pero también como la ruptura del binarismo de la identidad (y orientación) sexual. La conciencia del sexo es un obstáculo más para el artista, pero Woolf no prescinde de la sexualidad, del cuerpo: como apunta Wright (2006: 15), la androginia no responde a la negación de la sexualidad, más bien Woolf parece abogar por «esta curiosidad sexual que solo se logra cuando el sexo es inconsciente de sí mismo» (2001: 126). El sexo como ficción construida en los tratados, en las historias, en los poemas, que controla los individuos, asignándoles unos comportamientos sociales adecuados a su naturaleza, es una de las ideas principales que subyacen a la narración de Orlando.

Desde el inicio de la novela, Woolf se sirve de una ironía mordaz para hablar del sexo/género. El narrador, un biógrafo que recopila la vida y las hazañas de Orlando, da comienzo así a su relato: «Él porque no cabía duda sobre su sexo, aunque la moda de la época contribuyera a disfrazarlo- (...)» (1995: 235). En esta frase se condensa gran parte de la concepción de Woolf sobre el género: en primer lugar, el sexo de Orlando, supuestamente unívoco, está oculto bajo sus ropas, pero también, como indica la versión original, bajo la moda (fashion), que opera sobre los individuos de una sociedad. Así, el sexo se halla condicionado por los dictámenes sociales, y se revela a través de las ropas, de un comportamiento determinado, con la posibilidad, sin embargo, de jugar con esas ropas (restricciones) para superar el sexo/género, como se verá en el travestismo.

En efecto, las ropas en Orlando marcan una gran diferencia entre mujeres y hombres en las sociedades y épocas en que el protagonista se mueve, y bien podrían funcionar como un indicio de la

\footnotetext{
${ }^{19}$ Aunque en algunos fragmentos parece apuntarse a la diferenciación sexual, Woolf matiza su concepto de androginia en el siguiente pasaje: «Pero convenía averiguar qué entendía uno por "hombre con algo de mujer” y por "mujer con algo de hombre" (...). Quizá la mente andrógina está menos inclinada a esta clase de distinciones que la mente de un solo sexo» (2001: 133); la cursiva es nuestra. Veremos más adelante, además, en qué modo puede conectarse la teoría de Woolf con la de Haraway. Por otro lado, la ambigüedad del andrógino suponía, según Gascón-Vera, un intento de superar tanto las dificultades de las mujeres artistas como los propios miedos persona-les de Woolf: la violencia sexual o su rechazo al matrimonio burgués. De ahí que recurra a «un sujeto alternativo dentro de la ambigüedad del ser o del no ser, de lo masculino y de lo femenino» que es el andrógino $(2002: 100,101,107)$. Solo mediante la apropiación de ambos sexos (el masculino, tradicionalmente, el autor, y el femenino, la creadora, la madre de las ideas) podía restaurarse una identidad femenina que había sido construida a imagen de la del hombre (Gascón-Vera, 2002: 103 y 104).
} 
Ana Sánchez Anguix. Andróginos y ciborgs...

opresión del sexo y de los roles de género (Rogsntad, 2012: 46); así lo de-muestra, por ejemplo, el pasaje en que Orlando, una vez convertido en mujer, reflexiona sobre las restricciones del sexo femenino (pureza, dependencia de los hombres):

En circunstancias normales una muchacha linda y sola no hubiera pensado en otra cosa: el edificio entero de la moral femenina descansa en esa piedra fundamental; la pureza es su joya, su eje central, que deben proteger hasta la locura y a cuya pérdida no deben sobrevivir (...). “Señor, (...) qué vida más holgazana y más linda. (...) Nunca he visto mi piel (...) lucir como ahora. ¿Podría, sin embargo, saltar por la borda y nadar con semejante ropa? ¡No! Luego, tendría que confiarme a un marinero. ¿La idea me molesta? ¿Sí o no?...”, se preguntó, encontrando aquí el primer nudo en el hilo parejo de su argumento (Woolf, 1995: 329 y 330).

El cambio de sexo en Orlando, que se lleva a cabo de un modo fantástico ${ }^{20}$ y que, a nuestro parecer no responde sino a la ambigüedad sexual del protagonista desde el principio de la novela, es otro de los motivos principales de los que Woolf hace uso para hablar de la fantasía o construcción del género $^{21}$. Esta metamorfosis opera un cambio de perspectiva en Orlando:

Recordó cómo de muchacho había exigido que las mujeres fueran sumisas, castas, perfumadas y exquisitamente ataviadas. "Ahora deberé padecer en carne propia esas exigencias”, pensó, “porque las mujeres no son (a juzgar por mí misma) naturalmente sumisas, castas, perfumadas y exquisitamente ataviadas (Woolf, 1995: 331).

Como la androginia que Woolf defendería un año más tarde en su ensayo, Orlando es capaz de ver a través del prisma de ambos sexos, posee esa ambigüedad andrógina que le permite entrever las diferencias construidas entre los géneros, pero quizás su transformación no hace sino materializar dicha ambigüedad latente ya en los primeros capítulos de la novela, porque «nadie mostró la menor duda de que el Orlando de hoy no fuera el Orlando de ayer» (1995: 340), se dice cuando vuelve a su casa de Inglaterra, ya como mujer. En efecto, hay ya en el inicio una ambigüedad en la descripción de la belleza de Orlando, ya que conjuga la fuerza, la dureza de la masculinidad, con la luz, la pureza y el erotismo propios de los retratos poéticos femeninos (Rognstad, 2012: 35):

\footnotetext{
${ }^{20}$ La transformación de Orlando parece revestirse de tintes míticos cuando se habla de un amor andrógino, ambiguo, dado que el protagonista ama a hombres que resultan ser mujeres, a mujeres que semejan hombres, a mujeres que finalmente son hombres, antes y después de su metamorfosis; la descripción que se hace aquí parece remitir al mito platónico, al que se añade la pluralidad sexual: «Pues el Amor (...) tiene dos caras: una blanca, otra negra; dos cuerpos: uno liso, otro peludo. Tiene dos manos, dos pies, dos colas, dos, en verdad, de cada miembro y cada uno es el reverso exacto del otro. Sin embargo están ligados tan estrechamente que es imposible separarlos» (Woolf, 1995: 306).

${ }^{21}$ Rognstad (2012: 50) pone en relación el relato fantástico con la intención de la autora, ya que la fantasía (la metamorfosis de Orlando, una vida de más de tres siglos) permite encauzar la crítica de los roles de género escapan-do a la censura.
} 
Ana Sánchez Anguix. Andróginos y ciborgs...

Así, los que gustan de los símbolos y tienen habilidad para descifrarlos, podrían observar que aunque las hermosas piernas, el gallardo cuerpo y los hombros bien hechos estaban decorados todos ellos con diversos tintes de luz heráldica, la cara de Orlando, al abrir la ventana, sólo estaba alumbrada por el sol. Imposible encontrar cara más sombría y más cándida (...) El rojo de sus mej̈llas era aterciopelado como un durazno (...). Los labios eran cortos y ligeramente replegados sobre dientes de una exquisita blancura de almendra. (...) ¡Ay de mí!, pocas personas nacen desprovistas de estos tres atributos; pues cuando miramos a Orlando parado en la ventana, debemos admitir que tenía ojos como violetas empapadas, (...) y una frente como la curva de una cúpula de mármol apretada entre los dos medallones lisos que eran sus sienes (Woolf, 1995: 236 y 237$)^{22}$.

Idéntica amalgama de lo femenino y lo masculino se muestra en la descripción posterior a la transformación de Orlando, de una belleza cuyas «formas combinaban la fuerza del hombre y la gracia de la mujer» (Woolf, 1995: 319); pero, como ya advertíamos en nuestro comentario de Una habitación propia, la androginia según Woolf consiste en un estado ambiguo que pone en escena el deseo que escapa a la norma heterosexual y la opresión de la mujer en el ámbito social y político:

Orlando se había transformado en una mujer -inútil negarlo. Pero, en todo lo demás, Orlando era el mismo. El cambio de sexo modificaba su porvenir, no su identidad (...) Muchas personas, en vista de lo anterior, y de que tales cambios de sexo son anormales, se han esforzado en demostrar (a) que Orlando había sido siempre una mujer (b) que Orlando es ahora un hombre. Biólogos y psicólogos resolverán. Bástenos formular el hecho directo: Orlando fue varón hasta los treinta años; entonces se volvió mujer y ha seguido siéndolo (Woolf, 1995: 319 y 320).

La condición sexual de Orlando, pues, no puede reducirse a la dicotomía hombre/mujer ${ }^{23}$. Cuando, consciente de las restricciones sociales que se impone a la mujer, Orlando critique el sexo

\footnotetext{
${ }^{22}$ Señalamos en cursiva aquellas características que consideramos propias de la descripción de la belleza femenina, sobre todo en la tradición poética: la comparación de la pureza con el sol (que contrastaría con esa «luz heráldica», ligada al honor y a lo bélico, a los escudos), la alusión, muy frecuente en la novela, a las piernas, más asociadas al erotismo; el color de las mejillas, de los dientes, de los labios; el símil establecido con la arquitectura, figura muy recurrente en la lírica del Renacimiento, época en que se ubica el inicio del relato. Subrayamos, por el contrario, aquellos rasgos más vinculados a lo tradicionalmente considerado masculino: la gallardía del cuerpo, la robustez de los hombros, esa «luz heráldica» ya comentada. La tensión entre el Orlando masculino y femenino parece producirse, no solo por el contraste entre unos y otros rasgos que el narrador destaca, sino también por el valor simbólico que este confiere a la luz, que crea un efecto de claroscuro en el rostro del protagonista. Como veremos, este mismo efecto será también un modo de cubrir y descubrir el cuerpo del intersexual en la película $X X Y$.

${ }^{23}$ En este sentido, resulta de interés retomar la comparación que ya se hizo entre Butler y Woolf, ya que, como afirma Rognstad (2012: 32), ambas apuntan a «how what we take for granted as natural features of one gender is really traits that have been designed to that gender over time, through social and political norms, and that are being performed, and repeated every day and thus reinforced as absolute features».
} 
masculino, el narrador afirmará: «Y aquí parecía por cierta ambigüedad en sus términos que condenara a los dos sexos imparcialmente, como si no perteneciera a ninguno; y en efecto, vacilaba en ese momento: era varón, era mujer, sabía los secretos, compartía las flaquezas de los dos» (Woolf, 1995: 332). Orlando es un andrógino, presenta una actitud alejada de lo estereotípico que abarca posibilidades múltiples no circunscritas a la norma (Gascón Vera, 2002: 108). La novela de Woolf rompe con los esquemas genéricos por medio de la forma y del contenido, abrazando desde la ironía sobre el biógrafo y el historiador hasta la deconstrucción de las polaridades sexuales, en busca de un discurso y de una sexualidad femeninas antes censuradas (Gascón-Vera, 2002: 105 y 106).

Se entiende ahora el andrógino en el proyecto literario y feminista de Woolf y cómo ese ser ambiguo y monstruoso servirá de vía para la deconstrucción de género. La escritura, otro de los temas fundamentales de Orlando, es uno de los espacios en que se mueve el protagonista andrógino. En la línea de Una habitación propia, se presenta la androginia como ese estado mental que se sitúa en las fronteras de uno y otro sexo y que hace al protagonista partícipe de ambas perspectivas: solo cuando Orlando, ya una mujer, haya experimentado esos dos puntos de vista, verá publicada «La encina», ese poema que tantos siglos llevaba escribiendo y revisando ${ }^{24}$.

\footnotetext{
${ }^{24}$ Sin embargo, Rognstad $(2012: 33,37)$ defiende la tesis de que, aunque las dos obras de Woolf estén en principio vinculadas, la androginia de Orlando difiere finalmente de la Una habitación propia, puesto que la mente andrógi-na requiere la conjunción equilibrada de ambos sexos, mientras que, tras la transformación, el sexo masculino y femenino «never intermix or operate at the same time; and hence Orlando as a woman does not fulfill the ideal status of androgyny». La experiencia de Orlando como mujer y como hombre solo le ayuda a cumplir más debida-mente su rol social, aunque presentado como una mera construcción (Rognstad, 2012: 34), lo cual consideramos contradictorio, ya que no responde, por ejemplo, al matrimonio tan poco convencional de Orlando con Shelmer-dine, en el que ninguno de los dos conoce el sexo del otro (Woolf, 1995: 395 y 399). Por el contrario, la autora cree que es al inicio de la novela cuando la androginia que preconizaba Woolf está más presente, como ya comenta-mos. Pero aquí interpretamos el cambio de sexo, no como la asunción de los géneros, sino como lo que en Butler se conoce como gender bender, la puesta en marcha de la inestabilidad genérica y del derrocamiento de los valores heteropatriarcales. Para ello, como se ha intentado demostrar a lo largo de este apartado, es necesaria la ambigüe-dad del andrógino.
} 
Ana Sánchez Anguix. Andróginos y ciborgs...

\section{La androginia en el cine y la literatura hispánicos contemporáneos}

\subsection{El cuerpo andrógino: la intersexualidad en XXY}

¿Cómo debemos reformular las limitaciones morfológicas idóneas que recaen sobre los seres humanos para que quienes se alejan de la norma no estén condenados a una muerte en vida?

Judith Butler

¿Cómo puede representarse un cuerpo situado en los márgenes de lo naturalizado por los discursos heteropatriarcales? ¿Cómo se escribe un cuerpo abyecto, cómo dibujar un ser que escapa de lo que es visible, los dos sexos? Es esta la cuestión que subyace a la figura del intersexual en el cine y en la literatura, que supone una puesta en duda de las identidades sexuales tradicionales. Como Butler afirma, el género no solo opera sobre los cuerpos normalizados, sino muy especialmente sobre los que se alejan de los binarismos heteropatriarcales; es así como se decide sobre lo que constituye humano y lo que devendrá finalmente monstruoso, anclado en las sombras (2007: 26).

Con una relectura de La historia de la sexualidad de Michel Foucault, Butler (2007: 196-224) vuelve a la luz el caso de Herculine, un/una intersexual francés/francesa del XIX. Como sucede aún en la actualidad (Villar, 2014), a Herculine le fue asignado el sexo femeni-no al nacer, pero años más tarde fue obligado/obligada a cambiar su sexo legal al masculino. ¿Qué relaciones de poder, se pregunta Butler (2007: 197) condenaron la morfología y sexualidad de Herculine? ¿Es realmente necesario determinar el sexo/género? ${ }^{25}$ Partiendo de esta crítica a Foucault, Butler (2007: 199 y 200) llega a la conclusión de que el sexo, como el género, es «inevitablemente reglamentador, y cualquier análisis que presuponga esa categoría afianza y legitima todavía más esa táctica reglamentadora como un sistema de poder/conocimiento» (véase nota 12).

Pero más que el análisis de Foucault, interesa aquí retomar la expresión por parte de Herculine de su propia experiencia, similar a la de la/el protagonista de $X X Y$, Álex. Si aquel/aquella alude a su cuerpo subrepticiamente y alude en sus últimas páginas a la soledad antes del suicidio (Butler, 2007: 202), en la película de Lucía Puenzo, el cuerpo de Álex aparecerá medio sumido en la penumbra,

\footnotetext{
25 Preciado (2014a) recuerda la invención del término género, que servía en los centros pedopsiquiátricos para subrayar la condición inestable de aquellos cuerpos infantiles que no encajaban en el binario masculino/femenino. Frente al sexo, el género podrá alterarse mediante tratamientos hormonales o procedimientos quirúrgicos; ambos constituyen uno de los temas de $X X Y$.
} 
situándose en la ambigüedad sexual, y el personaje vivirá en un espacio alejado de la ciudad y ubicado en una naturaleza casi salvaje, junto al $\mathrm{mar}^{26}$.

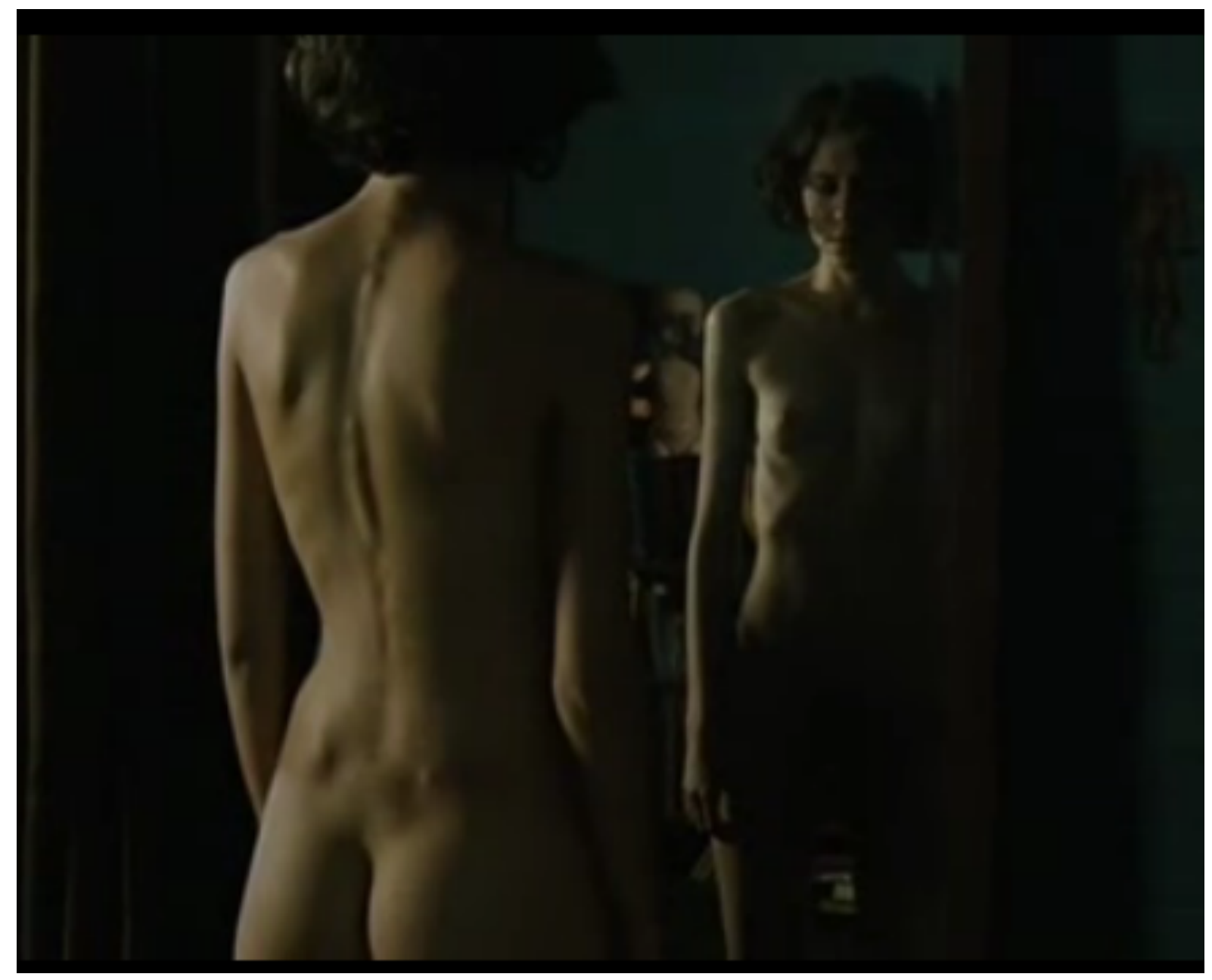

¿Podemos estar seguros de que lo que vemos se corresponde con las categorías con las que tradicionalmente hemos definido el mundo? (Butler, 2007: 27 y 28); la luz revela un cuerpo femenino, pero la oscuridad oculta un secreto, una abyección, una ruptura de los sexos: es este el juego de la

\footnotetext{
${ }^{26}$ Clark (2012: 5) analiza el espacio en términos de oposición entre dos mundos distintos: mientras que Álvaro, amigo de Álex, es capaz de atravesar las barreras o límites de su casa, el lugar de su reclusión, sus padres, Ramiro y Erika, casi huyen despavoridos de este entorno; esto se traslada a la concepción de los límites del género, que unos conciben de un modo más flexible y fluido que los otros. El espacio se revela, pues, como un espacio opresor, que busca contrastar la vastedad del paisaje marino con los primeros planos, según confiesa la propia directora (Clark, 2012: 7).
} 
escena $^{27}$. Ya en el cartel de la película, la ambigüedad remite a la intersexualidad de Álex: su cuerpo se cubre y se descubre de modo similar a otro/otra intersexual, la/el de El hermafrodita dormido de Bernini:
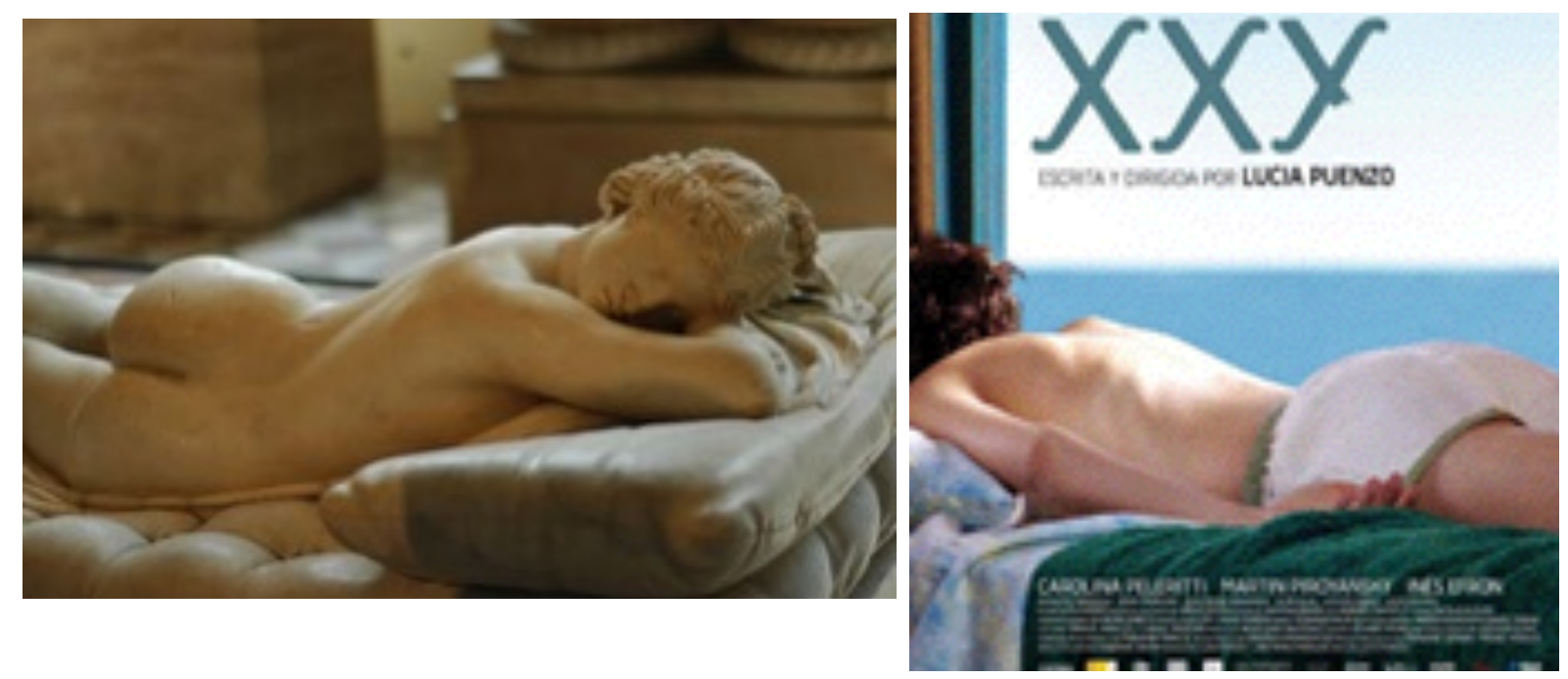

También la experiencia de lo sexual en estos personajes se vuelve difusa, y supera los límites de las relaciones homosexuales o heterosexuales convencionales; la película, en efecto, va más allá de los planteamientos feministas (sin negarlos, en verdad), y se adentra en el terreno de lo queer: tanto Herculine como Álex disfrutarán de su sexualidad, pero siempre en secreto: el/la primer/primera con Sara (Butler, 2007: 203), el/la segundo/segunda con Álvaro ${ }^{28}$; en el caso de Álex, podemos poner en relación ese espacio aparta-do de la urbe e inscrito en la naturaleza con la posibilidad de plantear la sexualidad independientemente del género/sexo. La intersexualidad de Herculine -pero también la de Álex- pone en duda la identificación entre morfología (cuerpo) y género, que «varía constante-mente (...) en relación con la dirección y los objetos de su deseo»; la dualidad típica se quiebra en la conjugación de las características de ambos sexos, la androginia de Herculine y de Álex «tiene el efecto de mostrar el

${ }^{27}$ La imagen de un cuerpo sumido en las sombras parece constituir una constante en la representación de los cuerpos abyectos: también en las crónicas de Pedro Lemebel se juega con los claroscuros para dar cuenta de encuentros sexuales que escapan a la heteronorma; en este caso, la vigilancia es la que crea ese espacio de luces y sombras en las que los amantes consuman su deseo (Peris, 2001: 233).

${ }^{28}$ Para Butler (2007: 207), en efecto, «la sexualidad de Herculine genera una serie de transgresiones de género que desafía la diferenciación misma entre intercambio erótico heterosexual y lésbico, y resalta los puntos de su convergencia y redistribución ambiguas». 
Ana Sánchez Anguix. Andróginos y ciborgs...

carácter ilusorio del sexo como un sustrato sustantivo permanente al que en apariencia se adhieren esos diferentes atributos» (Butler, 2007: 205-207).

La inestable identidad de Álex se aprecia tanto en lo corpóreo como en lo lingüístico, ya que desde su nombre, masculino y femenino a un tiempo, se reafirma su condición fronteriza, con que derriba el modo en que se establecen las relaciones de género: «en el preciso instante en que por primera vez marcamos el cuadradito al lado de la F, ingresamos en el sistema sexo-género» (Lauretis, 1989: 18; también en Butler, 2002: 25), pero Álex decide permanecer en la ambigüedad sexual, con todo lo que ello implica. El nombre, en el psicoanálisis, sostiene «la integridad del cuerpo»; así, puede entenderse que se halle condicionado políticamente, que a través de él se ejerza el control sexual y genérico (Butler, 2002: 115), pero que también constituya -añadimos- una vía de escape a dicho control.

En relación con el espacio, Clark (2012) pone el acento en la «humanimalidad» de $X X Y$, que desestructura no solo las categorías de género, sino también la dicotomía humano/no-humano, de un modo similar a como hará Haraway en su Manifiesto ciborg. En la película argentina, se establece una comunión entre Álex y la naturaleza, lo cual apunta a la condición humana (y natural) del cuerpo intersexual, frente a otros discursos que lo sitúan en lo monstruoso o abyecto; asimismo, Kraken, con quien se identifica Álex, es un defensor de los animales, y aboga por la integración de otros seres vivos en lo natural (los invertebrados, su propia hija) (Clark, 2012: 20). El marco marítimo ofrece además una serie de referencias al hermafroditismo que enlaza con la inclusión de estos cuerpos abyectos en la naturaleza, con la que Álex y Álvaro parecen fundirse cuando ocultan su rostro en un caparazón (la capucha) o los animales irrumpen en escena (las tortugas, los peces payaso, la iguana que repta por la pierna de Álex sin que por ello deje de existir una perfecta armonía) (Clark, 2012: 13-15) ${ }^{29}$.

La normalización supone que «la materialización del cuerpo ya no puede concebirse independientemente de la materialidad de esa norma reguladora», que se efectúa por medio de la asunción del sexo (Butler, 2002: 19). La figura del intersexual logra desestabilizar, desde una "posición desnaturalizada», al margen, lo considerado natural: la adscripción a uno u otro sexo resulta innecesaria e inútil, y se descubre, al fin, el carácter ficticio de las dicotomías sexuales, rotas por la aparición de un ser que escapa a esos moldes (Butler, 2007: 222 y 223). Se establece así una tensión en el film entre «la

29 Peidro (2013: 74 y 75) señala a este respecto los créditos iniciales, donde alternan imágenes de un paisaje de flores subacuáticas «presumiblemente hermafroditas por su forma, aspecto y funcionamiento», símbolo del intersexual, y una escena en la que Álex corre por el bosque con un cuchillo en la mano, que apunta a la mutilación o castración a la que vería sometido su cuerpo para encajar en los patrones sexuales. Resulta curiosa la conexión que puede establecerse aquí entre androginia y ciborgs, relación que analizaremos más detenidamente; Haraway (1995: 1 y 2) apunta así a la ruptura de la sexualidad heteropatriarcal que tanto ciborg como andrógino llevan a cabo: «El "sexo” del cyborg restaura algo del hermoso barroquismo reproductor de los helechos e invertebrados (magníficos profilácticos orgánicos contra la heterosexualidad». 
aceptación de cuerpos, deseos, eróticas, amores y goces diversos» y aquel discurso que intenta ligar sexo, género y sexualidad en base al patrón hegemónico (Peidro, 2013: 88) ${ }^{30}$.

Pero al tiempo que el intersexual resulta en estos textos transgresor, también es el objeto de una violencia que ejerce especialmente el discurso médico, el cual niega una «heterogeneidad que, en otros sentidos, sería natural» e impone «la naturalización binaria y asimétrica de los cuerpos» (Butler, 2007: 216 y 217$)^{31}$. Peidro (2013: 80 y 81) destaca así la figura del cirujano (Ramiro, el padre de Álvaro), que pretende modificar el cuerpo del intersexual para así incorporarlo como mujer a las categorías sexuales normalizadas, tarea que forma parte de la biopolítica según Foucault. En este sentido, la desviación de la normalidad sexual supone que se ejerza sobre los cuerpos abyectos la vigilancia de una «policía de género»: el padre de la amiga de Álex y el grupo de adolescentes que persiguen a el/la protagonista para ver sus genitales y que ejercen sobre él/ella la violencia de una violación; a este acoso ejercido sobre su cuerpo, Álex y su familia se verán además obligados a la dolorosa situación de guardar silencio ante la autoridad, que provocaría un mayor escándalo (Peidro, 2013: 81-83).

\footnotetext{
${ }^{30}$ Resurge aquí la definición que antes señalábamos para la androginia, que altera la narración «hasta llegar a su-mirlo en los derroteros de lo incierto, haciendo sucumbir los constructos identificatorios que separan, sustentándo-se en un disformismo genital, al macho de la hembra (...) y, en consecuencia, la elección de un objeto de deseo» (Vásquez, 2001: 180).

${ }^{31}$ Butler (2007: 217 y 218) retoma en este sentido el trabajo de David Page y su equipo, encargados de buscar el gen maestro que señalase de forma inequívoca la naturaleza dicotómica de los sexos; estos investigadores aventu-raron que al menos un $10 \%$ de la población mundial poseería variaciones cromosómicas que no se correspondieran con el patrón femenino XX y el masculino XY; sin embargo, la parte del ADN que determina el sexo masculino estaba presente en los cromosomas X de la mujer, lo cual habría derrumbado científicamente la dualidad de las ca-tegorías sexuales. Respecto a la explicación de Page en los hombres la secuencia de genes está activa, y en las mujeres, pasiva- Butler (2007: 222) afirma: «Es todavía más difícil diferenciar entre el sexo y el género cuando somos conscientes de que los significados provistos de género enmarcan la hipótesis y el razonamiento de las in-vestigaciones biomédicas cuyo objetivo es precisar cómo es el "sexo" antes de los significados culturales que ad-quiere. En realidad, la tarea se complica todavía más cuando nos percatamos de que el lenguaje de la biología in-terviene en otros tipos de lenguaje y reproduce la sedimentación cultural en los objetos que quiere descubrir y des-cribir con neutralidad».
} 
Ana Sánchez Anguix. Andróginos y ciborgs...

\subsection{Lo animal y lo diabólico: la intersexualidad de Adrián/Adriana en Las joyas de la serpiente}

El tiempo del animalismo es el de lo imposible y lo inimaginable. Ese es nuestro tiempo: el único que nos queda. (...) El feminismo es un animalismo. $\mathrm{O}$ por decirlo de otro modo, el animalismo es un feminismo expandido y no-antropocéntrico

Beatriz Preciado

Ya hemos visto cómo la androginia e intersexualidad de Álex permiten hacer tambalear las nociones heteropatriarcales de sexualidad e identidad de género; pero también observamos una conexión del/la intersexual con la naturaleza que pone en duda las viejas distinciones entre lo humano y no humano. Haraway (1995: 4) señala esta misma ruptura con respecto a la figura del ciborg, y habla de un lugar en que «la frontera entre lo animal y lo humano es transgredida». La intersexualidad supone en primera instancia una mezcla centáurica, una fusión que se ubica en los límites entre los sexos, compartimentos que excluyen lo andrógino de lo humano: ¿cuál es, entonces, su lugar? Preciado (2014b) relaciona los proyectos feminista y antiesclavista con el animalista, en el sentido de que los tres intentan rasgar las categorías que han impedido, durante la implantación del capitalismo, la libertad de mujeres, esclavos y animales ${ }^{32}$.

En Las joyas de la serpiente, el personaje intersexual une en su cuerpo características de ambos sexos con las garras de una bestia, dibujando un ser que se sitúa fuera de lo huma-no, en el terreno de lo monstruoso y de lo diabólico. El carácter subversivo de esta unión lo apunta también Haraway (1995: 35) cuando retoma las figuras mitológicas de centauros y amazonas, estas últimas también presentes en la novela de Pilar Pedraza ${ }^{33}$ :

Los monstruos han definido siempre los límites de la comunidad en las imaginaciones occidentales. Los centauros y las amazonas de la Grecia antigua establecieron los límites de la polis central del ser humano

\footnotetext{
32 En Haraway (1995: 28) la unión de las categorías de lo humano con lo animal supondrá una vía de escape a un lenguaje totalizador ligado al capitalismo; el «lenguaje quimérico» equivaldrá a «no ser un Hombre, la encarnación del logos occidental».

${ }^{33}$ Las joyas de la serpiente es una novela gótica en que el protagonista, Bartolomé, se embarca en un inesperado viaje hacia lo sobrenatural y los confines del conocimiento a partir de su relación con Adrián/Adriana, Blanca y otros personajes. En los últimos capítulos, Bartolomé se adentra en lugares infernales e ignotos, cada uno habitado por personajes pintorescos y sanguinarios. En uno de estos moran las Lilithitas, una comunidad de amazonas liderada por Lilith, la cual «era hermafrodita y no necesitaba del concurso del varón para engendrar»(Pedraza, 1984: 177-179).
} 
Ana Sánchez Anguix. Andróginos y ciborgs...

masculino griego mediante la disrupción del matrimonio y las poluciones limítrofes del guerrero con animales y mujeres.

Lo monstruoso «ayuda a redifinir los placeres y la política de la encarnación en la es-critura feminista», y supone un planteamiento «problemático» de lo que se considera huma-no (Haraway, 1995: 34 y 35). Como sucedía con Álex en $X X Y$ o con el/la protagonista de Orlando, en Las joyas de la serpiente se juega con la luz y la oscuridad para crear un halo de misterio en torno al cuerpo andrógino y medio animal de Adrián/Adriana ${ }^{34}$; así, en el capítulo IV del libro I, se dice de este personaje: «los pocos rasgos que la luna iluminaba eran de una belleza exquisita y un tanto maligna, y sus ojos brillaban en la penumbra como los de los gatos» (Pedraza, 1984: 23 y 24). Y en el capítulo V:

La mano que llegué a entrever me pareció terriblemente monstruosa (...) tenía cierto retorcimiento, cierta crispación, como la garra de un animal, y aunque era fina y blanquísima, estaba cubierta de pelos largos, negros y muy gruesos. Las uñas eran largas, curvadas hacia dentro, oscuras y afiladas. He visto manos deformes, pero nunca tan extrañas como aquella, en la que se unía una delicadeza angélica a un no sé qué de bestial. Con el guante puesto se borraba inmediatamente esta impresión, y resultaba tan linda como la de la más delicada damisela.

Es aquí donde se funde lo femenino (la fina mano enguantada de una dama), lo masculino (Adrián aún es percibido por los demás como un joven), lo animal (la zarpa peluda de uñas afiladas), lo angélico y lo demoniaco, que apuntan a uno de los mensajes de la novela: un saber más allá de lo conocido, más allá de un pensamiento dicotómico con el que Bartolomé, un ser rechazado por la vida y la muerte será capaz de penetrar en las regiones más os-curas, donde se funden lo celestial y lo infernal. Dice don Gaspar, uno de los personajes clave de la novela: «Si deseáis alcanzar algún átomo de la sabiduría universal, debéis despoja-ros de vuestro maniqueismo y abrir vuestra mente por completo» (Pedraza, 1984: 34); así, la destrucción de categorías tradicionales (masculino/femenino, humano/no-humano, muerte/vida) lleva a un saber superior, pero también a una condición abyecta, alejada de esas dicotomías, de un modo similar a como Virginia Woolf advertía de lo monstruoso de las mentes andróginas (véase nota 18).

La construcción de la novela también resulta interesante: por un lado, el marco histórico y social de los Siglos de Oro sitúa la acción en un momento donde la misoginia era extrema, y así son frecuentes comentarios como este: «Tiene también algo del oscuro conocimiento de las cosas propio de las mujeres, mucho más penetrante que el de los hombres, aunque carezca de su claridad» (Pedraza, 1984: 34). Se establece, pues, una tensión entre un entorno «maniqueo», prejuicioso, y los personajes como Adrián/

\footnotetext{
${ }^{34}$ Esta cita recuerda al recurso de los claroscuros para ocultar y revelar el cuerpo andrógino, que ya vimos en Orlando y en $X X Y$; los textos de nuestro corpus, por tanto, guardan una relación más estrecha que la simple coincidencia temática, puesto que se observan también similitudes formales o de construcción.
} 
Ana Sánchez Anguix. Andróginos y ciborgs...

Adriana, que escapan a las categorías que regulan el pensamiento normalizado. Por otro lado, el género fantástico permite jugar con la sexualidad y el erotismo ${ }^{35}$, ligados a lo demoniaco, a lo prohibido; en este sentido, la anagnórisis de Bartolomé al final del libro I -titulado significativamente Los aprendizajespermite consumar un deseo no heterosexual que palpitaba oculto ${ }^{36}$ :

Adrián se quitó el sombrero y los guantes. Por segunda vez en muchos años pude contemplar sus manos deformes y exquisitas, aquellas delicadas garras de marfil cubiertas de pelos negros y armadas con unas uñas amoratadas, poderosas y afiladas como las de una fiera. Luego continuó quitándose prendas con ademanes naturales y encantadores, hasta quedar completamente desnudo, o desnuda, porque ante mi asombro comprobé que su cuerpo era la más hermosa y extraña mezcla de rasgos de varón y de mujer que un loco delirio puede concebir.

Adrián, o Adriana, pues ambos nombres cuadraban a su doble naturaleza, se tendió en el lecho negro y me atrajo hacia sí (Pedraza, 1984: 76).

Adrián/Adriana es el personaje central de la trama; es él/ella quien lleva tanto a Blanca ${ }^{37}$ como a Bartolomé a los límites entre lo normalizado y lo monstruoso, entre lo muerto y lo vivo, entre lo angélico y lo infernal; y, al contrario que otros seres demoniacos propios de la novela gótica, no es ni hombre ni mujer, ni animal ni humano, lo que permite desmon-tar el tópico de la mujer diabólica y fatal: la figura de Adriana/Adrián permite cuestionar, por el contrario, las categorías que rigen el pensamiento del heteropatriarcado, de ahí su carácter de guía en los terrenos menos visibles para la mente humana. La

35 En este sentido, Todorov (1981: 120) señala lo transgresor de lo sobrenatural, tanto en el ámbito social como en el literario: «Ya sea dentro de la vida social o del relato, la intervención del elemento sobrenatural constituye siempre una ruptura en el sistema de reglas preestablecidas y encuentra en ello su justificación». Asimismo, establece unos campos temáticos para el género fantástico, entre los que es clave el erotismo: las relaciones entre hombres y diablesas, la homosexualidad, los amores vampirescos; deseos extraños y clandestinos que estallan en las ficciones de fantasía: «Más allá de este amor intenso pero "normal" por una mujer, la literatura fantástica ejemplifica diversas transformaciones del deseo. La mayor parte no pertenecen verdaderamente a lo sobrenatural, sino más bien a lo "extraño" social» (Todorov, 1981: 96).

${ }^{36}$ Se trata de un amor latente porque, con anterioridad, Bartolomé ya había sentido una inevitable atracción hacia Adrián: «Había algo en su persona que ahuyentaba cualquier suspicacia y hacía que le amase sin reservas y con una clase de amor muy superior al que se siente por las mujeres y por los amigos (...). He de confesar, además, que me atraía hacia su persona una inclinación que cualquiera podría tachar de nefanda, ya que en ocasiones llegaba a desearle amorosamente. Al principio esta inclinación me asustó (...), aunque, en un vano intento de justificar-me, la achacaba al aspecto femenino y suave de Adrián, que le hacía semejante a una linda muchacha» (Pedraza, 1984: 55). He aquí un ejemplo similar a ese amor andrógino que ya habíamos observado en Orlando (véase nota 20).

${ }^{37}$ En el capítulo VIII del libro II, en efecto, Blanca confiesa a Bartolomé su relación lésbica con una joven que responde a las características físicas de Adriana: su «belleza resplandeciente hacía pensar antes en los demonios que en los ángeles», sus pensamientos, «aunque se dirigieran a cosas nimias, eran siempre agudos y atrevidos como los de un muchacho» y siempre llevaba «unos guantes oscuros y muy tupidos» (Pedraza, 1984: 100-103). Vemos cómo en la novela, el personaje andrógino plantea una sexualidad y un erotismo poco convencionales, al tiempo que rompe con las dicotomías del género. 
Ana Sánchez Anguix. Andróginos y ciborgs...

novela termina precisamente con el autodescubrimiento de Bartolomé de la mano de su amante -es un «rechazado por la Muerte»- y el protagonista acaba así afirmando su condición abyecta: «No hay sitio para nosotros en ninguno de esos reinos» (Pedraza, 1984: 183).

\subsection{Travestismo, androginia y poder patriarcal: narraciones de Gorodischer y Ocampo}

A lo largo del libro I de Las joyas de la serpiente, persiste la sensación de que Adrián es en realidad una mujer vestida de hombre: «al principio no le reconocí, porque iba muy arrebujado en su capa, aunque no hacía frío, y el chambergo ocultaba y ensombrecía sus delicadas facciones (...). Estaba tan lindo que parecía una muchacha disfrazada» (Pedraza, 1984: 37); "Acarició con su fina mano enguantada sus pesados rizos rojos, y su ademán hizo que tuviera yo más que nunca la impresión de que era una muchacha disfrazada» (Pedraza, 1984: 41). Las ropas ayudan así a configurar la imagen del andrógino, de un modo similar a como ya vimos en Orlando, donde la vestimenta podía significar tanto liberación como opresión sexual (Rognstad, 2012: 46 y 47).

Esta última es una idea que también aparece en Butler (2002: 184), que rechaza el ca-rácter transgresor inherente al travestismo: «el travestismo es un sitio de cierta ambivalencia» (la cursiva es nuestra), la cual puede inclinarse bien a la «naturalización», bien a la «re-idealización» (ib.); como la del andrógino, la ambigüedad sexual del travestismo persigue la desestructuración del género dual, aunque mediante un reflejo de esa dicotomía (Butler, 2002: 185). El travestismo acaba siendo más una puesta en escena del funcionamiento de los roles de género que un acto subversivo per se (Butler, 2007: 27). Ahora bien, esta exhibición de las relaciones de género puede resultar una simple mímesis o una crítica al heteropatriarcado: «la promesa esencial del travestismo no tiene que ver con la proliferación de géneros (...), antes bien lo que ofrece es un modo de exponer, de poner en evidencia la incapacidad de los regímenes heterosexuales para legislar o contener por completo sus ideales»(Butler, 2002: 333$)^{38}$.

Si el género se perpetúa mediante una serie de actos, ¿pueden estos mismos actos en el travestismo quebrar las relaciones de género? (Butler, 2007: 37). Pedraza (1998: 173) re-cuerda la teoría criminológica de Lombroso como una de las primeras que justificaban científicamente la inferioridad intelectual de la mujer; este autor sostenía «que algunas mujeres de talento de su época parecen hombres travestidos». El travestismo como una práctica subversiva podrá jugar con esas suposiciones misóginas poniendo en marcha una especie de intrusismo genérico en el que las mujeres

\footnotetext{
${ }^{38}$ También Hueso (2012: 306) recuerda que «produciendo una "realidad” por sí mismo», el travesti «muestra la "realidad” de la construcción del otro como mera falsedad»; en otras palabras, el travestismo supone una subversión en tanto que niega una identidad sexual a priori (en Ostrov, a través de Hueso, 2012: 306).
} 
Ana Sánchez Anguix. Andróginos y ciborgs...

desempeñarán funciones en principio restringidas a los hombres o los personajes disfrutarán de una sexualidad más allá de las dicotomías hombre/mujer y heterosexualidad/homosexualidad ${ }^{39}$. La androginia se corresponderá aquí con una figura que se olvida de su sexo (recordando a Woolf) y cuya actitud desafía las restrictivas leyes heteropatriarcales.

Este es el caso de algunos cuentos fantásticos de la escritora argentina Angélica Gorodischer. En Kalpa imperial, Gorodischer agrupa una serie de relatos en torno a un imperio ficticio ubicado en un tiempo y un espacio míticos. El tratamiento del género en esta autora es bastante peculiar: si bien su proyecto literario se enmarca dentro de una literatura de mujeres - y constituye, por tanto, un feminismo de la diferencia-, su propuesta literaria en Kal-pa imperial se acerca a la androginia según Virginia Woolf (López, 2009: 55 y 65) ${ }^{40}$. El deconstructivismo de Gorodischer consistirá, pues, en una caracterización de los personajes que quiebra la concepción dual del género: las mujeres son sabias y guerreras, pero sin resultar por ello masculinas (ib.); por el contrario, parecen poseer esa combinación de lo tradicionalmente varonil y femenino que les confiere, finalmente, un estado andrógino, confuso y ambiguo.

De este modo, en Acerca de las ciudades que crecen descontroladamente, el narrador nos traslada la historia de una ciudad que ha visto su esplendor y su decadencia y en la que destacó la figura de una mujer que, pese a su condición social, llegó a ser emperatriz. De ella se nos dice que fue «Jefe de las Fuerzas de Vigilancia Interna» (Gorodischer, 2000: 85), cargo que había ganado «disfrazada de hombre, demostrando mayor capacidad y destreza en la lucha con armas y a mano desnuda que todos sus

${ }^{39}$ Hablamos aquí de personajes ficticios, pero también algunas mujeres en la historia practicaron el travestismo para acceder a puestos reservados exclusivamente a hombres. Ferrús (2001: 45-50) recuerda el caso de la «Monja Alférez» Catalina de Erauso (1685?-1650), que escapó del convento y que, oculta bajo ropas masculinas, logró ser militar. En su autobiografía emerge la androginia como la apropiación de un acto masculino -la escritura- desde un espacio disidente, el femenino. Su atrevimiento no recibió castigo por parte de las autoridades: la autobiografía de la Monja Alférez asume un pacto patriarcal según el que las monjas debían escribir sus confesiones, pero, al mismo tiempo, quiebra estos convencionalismos desde el interior, ya que Catalina logra adueñarse de su propio discurso (Ferrús, 2001: 49-50).

40 Cabría preguntarse entonces de qué manera Gorodischer rompe con lo establecido en la escritura femenina, don-de la experiencia de la mujer supone el «destino de una anatomía», la asunción de unos patrones culturales específicos (Mattalía, 2003: 22). En los cuentos de Gorodischer se habla desde un afuera de la tradición: la voz del narrador de cuentos hace acto de presencia en el relato, y los personajes femeninos se adentran en el mundo de los hombres casi desapercibidamente. Veremos más tarde cómo Gorodischer plantea una escritura de la disidencia, similar a la androginia de Woolf: ambas autoras se desprenden de su sexo y de su cuerpo para construir un discurso que va más allá de lo destinado a la mujer; tanto Orlando como los personajes femeninos de Gorodischer jugarán, así, con las convenciones establecidas para gozar de una libertad sexual censurada o para lograr sus propósitos. Una de las estrategias que se seguirán será precisamente el travestismo: la feminidad, una máscara que cubre el cuerpo femeni-no abyecto en la lógica falocéntrica (Mattalía, 2003: 84), es trocada por otro disfraz -el de hombre- con el que se logra alterar los roles de género y poner en duda la dualidad sexual: el andrógino aparece aquí, en la ambivalencia de un sujeto oculto entre las ropas de otro sexo. 
Ana Sánchez Anguix. Andróginos y ciborgs...

oponentes varones, que eran muchos» (ib.). La protagonista, más que resultar masculina alberga características tradicionalmente adscritas a ambos sexos pues reinó «duramente a veces, pero bellamente siempre» (Gorodischer, 2000: 86). Desde aquí puede leerse la deconstrucción (andrógina) de Gorodischer, puesto que las «viejas ropas de hombre» le sirven a la emperatriz para superar su doble condición social y de género; se construye en sus relatos una teoría, no de la femini-dad, sino de la disidencia y la marginalidad (López, 2009: 55).

Esta resistencia a las categorías patriarcales se realiza también en el plano formal, de la escritura, en especial por medio del narrador, una instancia corpórea que toma la voz en un nivel intradiegético y del que no conocemos ni nombre ni sexo. La subjetividad del narra-dor, sin embargo, sí está presente: como ocurría en Orlando, la narración corre a cargo de una figura cuya identidad se desvanesce, pero que, por una serie de pistas, podemos atribuir al contador de cuentos en Gorodischer o al biógrafo/ historiador en Woolf, respectivamente ${ }^{41}$. Esta perspectiva desde la que se le da voz permite mantener al narrador en la ambigüedad, subversiva como la identidad del andrógino, aunque aquí en términos de ostentación de la verdad, la otra cara del poder $^{42}$; se dice en Acerca de las ciudades que crecen descontroladamente: «Y nada era verdad, nada: ni los orígenes novelescos ni los nombres sonoros y fantasiosos. Yo soy el que les va a contar cómo sucedieron las cosas, porque es a los contadores de cuentos a quienes toca decir la verdad (...)»(Gorodischer, 2000: 73) ${ }^{43}$.

La verdad de la Historia, la verdad del género, la verdad del poder: estas se descubren a través de la ficción, de la leyenda, que el narrador traslada a su auditorio. En La vieja ruta del incienso nada es lo que parece, y el pícaro y la mujer que acompañan a un comerciante en un viaje hacia la capital terminan

\footnotetext{
${ }^{41}$ La escritura de Woolf y de Gorodischer se emparentan también por el lugar desde el que se narran sus relatos: la escritura termina siendo ese devenir en el que el sujeto puede despojarse del yo y quedar en un estado fronte-rizo que aquí se identifica con el andrógino: «una literatura menor no se define por su minoridad sino por el trato que inflige a la literatura mayor; una literatura que obliga a la lengua delirar, a salir de su surco» (Mattalía, 2003: 88).

42 La búsqueda del poder, uno de los temas fundamentales de esta colección de cuentos, no se lleva a cabo en fun-ción de unos intereses concretos, «sencillamente es poder y se desea (...) se detenta y se ejerce»; «el poder no tiene sexo» (López, 2009: 55). En estos relatos pueden relacionarse, pues, poder, verdad y género.

${ }^{43}$ La identidad del narrador la conocemos en un único cuento, Retrato de la emperatriz. El narrador como categoría narratológica deja de ser una instancia incorpórea y pasa a constituir un personaje de la historia que nos traslada; pero, ¿desde dónde nos habla de la protagonista de este cuento? Hay en muchos cuentos un nivel intradiegético, un lugar desde el que él porque ahora podemos confirmar su sexo- relata todas estas historias: un auditorio atesta-do de oyentes curiosos que acuden, en este caso, a escuchar la verdad acerca de la emperatriz más amada del Imperio. La caracterización de la protagonista no consiste aquí en esa unión entre lo masculino y lo femenino, sino principalmente en una sabiduría que el narrador califica de diferente; dice la protagonista: «mis hijos (...) no tienen que ser solamente fuertes y sanos y bellos, también tienen que tener esa veta de locura y de pasión que hace que un hombre o una mujer pueda ver el otro mundo que es la sombra de este y en el cual este es la sombra» (Gorodischer, 2000: 117).
} 
Ana Sánchez Anguix. Andróginos y ciborgs...

siendo, respectivamente, la princesa heredera del imperio y su fiel guardaespaldas. Aquí los roles de género se trocan de nuevo a través de las ropas. Desde el inicio del relato, a las afirmaciones feministas por parte de estos dos personajes se suma la sospecha del viejo mercader, al que la mujer le resulta inquietante: «el viejo hubiera apostado un dedo (...) a que era un nombre falso» (Gorodischer, 2000: 193).

La escena final del cuento supone la revelación de la identidad de la misteriosa mujer y de El Gato, caracterizados ahora con rasgos asignados tradicionalmente al sexo masculino y femenino: mientras la primera posee «una voz poderosa acostumbrada a dar órdenes» (Gorodischer, 2000: 211), el pícaro (la princesa) está dispuesto a combatir en la emboscada («iYo también sé pelear!»; Gorodischer, 2000: 212). La historia del origen del universo narrada por el comerciante y en que se habla de los «veinte rumbos del mundo» ratifica esa dificultad para conocer con certeza las cosas: «son veinte y los veinte llevan al bien y al mal, a lo vacío y a lo lleno, a lo móvil y a lo quieto, a lo blanco y a lo negro, y yo soy solamente un viejo que ha estado a punto de errar el camino» (ib.). Un comerciante lleno de experiencia y conocedor de los veinte rumbos no supo ver los que bajo las ropas se escondían; el género no es ni estático, ni superficial.

En un cuento de Silvina Ocampo, Las vestiduras peligrosas, las dos protagonistas, Piluca y Artemia, cumplen, respectivamente, con los dos tópicos de la feminidad: la mujer virginal y la fatal ${ }^{44}$. El relato trata de la creación de varios vestidos peligrosos que provocan en distintos países del mundo la violación de las mujeres que los llevan; Artemia, una mujer de clase alta para quien Piluca (o Régula) cose, muestra su indignación al ver que otras con-siguen lo que ella quería con idénticos vestidos. El cuento, en efecto, parece parodiar el argumento sexista que justifica las violaciones por la forma de vestir de las víctimas, y exagera el diseño de los vestidos y la reacción de Artemia con el fin de mostrar lo injusto y absurdo de esas afirmaciones. Piluca, que representa en el relato a la mujer altamente religiosa y recatada, ha sido capaz, no obstante, de vislumbrar el sexismo de la sociedad (recuerda las miradas

\footnotetext{
44 Ambos estereotipos están presentes en la película Metrópolis de Fritz Lang, donde María representa la mujer celestial, bondadosa y maternal, y su doble autómata, la rebeldía y la lujuria. Un análisis de estas dos figuras a partir del film se encontrará en Huyssen (1986). En el relato de Ocampo, la caracterización de los dos personajes responde a un polo o a otro de la feminidad: mientras que el comportamiento de Régula o Piluca refleja una moral restrictiva y ligada a la religión - por las múltiples imágenes relacionadas con el marianismo-, el afán de quedarse «inanimada, tendida y desgarrada en el suelo» de Artemia y su focalización en la belleza obedece igualmente a los designios del sistema patriarcal (Pérez: La identidad genérica). En este último caso, Solorza (2009: 112) señala lo contradictorio del modelo de belleza, ya que «la norma constriñe el cuerpo a la encarnación de un ideal estético pero, a su vez, encarnar el ideal, volverlo ostensible a través del desnudo, tendrá una repercusión violenta». De es-te modo, la transgresión final llevada a cabo por Artemia (y Régula) consiste en una actitud similar a la que adopta-ron otras mujeres en la historia -como George Sand-, renunciando a la belleza y a la feminidad: la travestida logra romper con la identidad de género y con su misma representación (ib.).
} 
Ana Sánchez Anguix. Andróginos y ciborgs...

lascivas de un cliente y su erección) (Pérez: La identidad genérica), y sugiere a Artemia la creación del más peligroso de los trajes: el de un hombre. Cuando Artemia salga esa noche vestida con una camisa a cuadros y un pantalón, un grupo de muchachos no solo la violarán, sino que la acuchillarán «por tramposa» (Ocampo, 1999: 25 ${ }^{45}$. Es este intrusismo genérico el que supondrá el verdadero peligro para el patriarcado.

En cambio, el travestismo en Orlando va más allá de dicho intrusismo y sirve como deconstrucción del género, como ruptura de cualquier norma sexual que limita las acciones y los deseos: «(...) son los trajes lo que nos usan, y no nosotros los que usamos los trajes» (Woolf, 1995: 352) ${ }^{46}$; partiendo de esta premisa, la novela explota el uso de las ropas para demostrar el carácter ficticio e irreal del género, ya sea como crítica al sistema (hetero)patriarcal y oposición a sus restricciones ${ }^{47}$, ya como vía para satisfacer una sexuali-dad que escapa de la simple diferenciación entre homosexualidad y heterosexualidad:

Los trajes no son otra cosa que símbolos de algo escondido muy adentro. Fue una transformación de la misma Orlando la que determinó su elección del traje de mujer y sexo de mujer. Quizá al obrar así, ella sólo expresó un poco más abiertamente que lo habitual -es indiscutible que su característica primordial era la franqueza- algo que les ocurre a muchas personas y que no manifiestan. De nuevo nos encontramos ante un dilema. Por diversos que sean los sexos, se confunden. No hay ser humano que no oscile de un sexo a otro, y a menudo sólo los trajes siguen siendo varones o mujeres, mientras que el sexo oculto es lo contrario del que está a la vista (Woolf, 1995: 352 y 353).

45 Pérez (La identidad genérica) ve en el acuchillamiento la anulación del cuerpo femenino que ha logrado subvertir las normas que determinan la feminidad; la trampa de Artemia, en cambio, permanece en la ambigüedad: «¿Qué es lo que desean castigar los asesinos? ¿Haber descubierto que en realidad su deseo homosexual no pudo ser satisfecho porque a quien violaron era finalmente una mujer? ¿El intento por parte de la protagonista de asumir un lugar que no le corresponde, de apropiarse del falo? ¿O ambas cosas?».

${ }^{46}$ Recordemos aquí el principio de la novela, donde, como ya señalamos, las ropas constituyen un elemento fundamental para representar ese carácter irreal del género. Rognstad (2012: 42) añade a esta idea la de la evolución de la moda, que demuestra, en efecto «how gender conventions and stereotypical characteristics of one gender are produced within a discourse existing at a specific time in a specific culture, which indicates that gender is not absolute, but rather constantly developing».

${ }^{47}$ Rognstad (2012: 40) añade la inspiración que pudo haber encontrado Woolf en su amante. Vita Sackville-West, como otras mujeres de su tiempo, vestía muchas veces como un hombre, aunque más que por satisfacer un deseo sexual por cuestiones políticas («but rather for social and political reasons»). Encontramos el paralelo en el siguiente pasaje de la novela: «Entonces se levantó y regresó a la casa, donde fue derecha a su cuarto y se encerró con llave. Abrió un armario donde estaban los trajes que había usado cuando era un gentilhombre (...). Dio un par de vueltas ante el espejo para cerciorarse de que las faldas no le habían hecho perder la soltura de las piernas, y salió secretamente a la calle» (370). 
Hacia el final de la novela, Orlando, ya una mujer, pone en práctica lo que veremos en los cuentos de Gorodischer y en el de Silvina Ocampo: el travestismo como liberación específicamente femenina, ya que Orlando altera su traje según la función social asignada a ambos sexos: así, usa el de mujer cuando recibe «la propuesta matrimonial de algún aristócrata», el de hombre, cuando, de noche, desea volverse «un noble de pies a cabeza (...) recorriendo las calles en busca de aventuras» (Woolf, 1995: 374). Pero también el travestismo le permite a Orlando ampliar la experiencia sexual: «(...) cambiaba de género con una frecuencia increíble para quienes están limitados a una sola clase de trajes. (...) Cambiaba la honestidad del calzón corto por el encanto de la falda y gozaba por igual del amor de ambos sexos» (ib.). En este sentido, la concepción del travestismo en Orlando adelanta la tesis de Butler (2002: 328):

El potencial crítico del travestismo tiene que ver principalmente con una crítica del régimen de verdad del "sexo" que prevalece, un régimen que considero profundamente heterosexista: la distinción entre la verdad "interior" de la femineidad (...) y la verdad "exterior" (...) produce una formación de género contradictoria en la que no puede establecerse ninguna "verdad” fija. El género, ni es verdad puramente psíquica (...) ni puede reducirse a una apariencia de superficie; por el contrario, su carácter fluctuante debe caracterizarse como el juego entre la psique y la apariencia (entendiendo que en este último dominio se incluye lo que aparece en las palabras ${ }^{48}$.

\footnotetext{
${ }^{48}$ A esta similitud entre la teoría de Butler y el travestismo en Woolf apunta también Rognstad: «masquerade and crossdressing become a way to perform a different type of gender outside of the existing norms, demonstrating that gender is not something absolute, and that there exists no such thing as gender core» (2012: 39-41). Y añade el hecho de que algunos personajes de la novela, como el Archiduque Harriet/Harry o el/la propio/propia Orlando, pongan en práctica la performatividad de los géneros teorizada por Butler; así, Woolf distingue entre actuar como un hombre o una mujer y caer en el «curso natural», en lo que conforma su subjetividad: «this indicates that Woolf sees the stereotypical gender conventions as fake, hence not natural, and that to operate according to them is to perform, or act» (Rognstad, 2012: 43).
} 


\section{Ciborgs}

\subsection{Andróginos y ciborgs: monstruos agenéricos}

Intentando escapar de lo binario entro en la cromozona, que no es una XXYXXYXXYXXYXXYXXYXXYXXYXXYXXYXXYXXYXXYX

heterofóllame, baby

la resistencia es inútil

Engátusame, machihémbrame, mapea mi genoma ABANDONADO

a imagen de tu proyecto

implícame artificialmente

quiero vivir eternamente

cárgame en tu brillante, brillante futuro de PVC, VNS matrix (Manifiesto de la zorra mutante) ${ }^{49}$

El género cyborg es una posibilidad local que cumple una venganza global. No existe impulso en los cyborgs para producir una teoría total, pero sí una experiencia íntima de las fronteras, de su construccón y de su deconstrucción. (...) Significa al mismo tiempo construir y destruir máquinas, identidades, categorías, relaciones, historias del espacio. A pesar de que los dos bailan juntos el baile en espiral, prefiero ser cyborg que una diosa

Donna Haraway

Los ciborgs son los nuevos dioses. En la era de la tecnología, el panóptico de Foucault llega a sus límites: la vigilancia se vuelve extrema y el cuerpo entra en el circuito de producción como autómata.

\footnotetext{
${ }^{49}$ Se trata de una de las primeras obras del arte ciberfeminista, movimiento basado en la propuesta de Donna Haraway para el feminismo socialista. En el fragmento escogido se puede ver cómo, en realidad, andrógino y ciborg forman parte de una misma imagen, rupturista con los convencionalismos genéricos y sexuales.
} 
Qué puede obtenerse de la fusión del humano y de la tecnología es la pregunta que se plantea Haraway, que funda una nueva teoría feminista donde el cuerpo se alía con lo no humano para dar fruto a un ser más allá de las dicotomías de género, raza y clase ${ }^{50}$. La deconstrucción de Haraway produce un nuevo monstruo que devora el orden naturalizado: andróginos y ciborgs, ambos suponen la ruptura con lo convencional y logran escapar en busca de una identidad sexual que derribe el dualismo heteropatriarcal; son monstruos de la modernidad que representan lo otro, lo abyecto (Robles, 2008: 621 y 622).

Se rechaza un proyecto feminista que postule dicotomías absolutas, ya que «no son inocentes» y «acaban proponiendo un sistema de segregación sexual» (Osborne, 2005: 227); por el contrario, se busca en la literatura y en el arte un espacio y un discurso nuevos, donde estos seres abyectos, excluidos de lo humano (Butler, 2002: 26) -el andrógino, el ciborg- puedan constituir «una amenaza para tales fronteras, pues indican la persistente posibilidad de derrumbarlas y rearticularlas» (ib.). El ciborg supone «un cuerpo híbrido y monstruoso», «atravesado de violencia en tanto que desestabiliza el cerco semántico» (Manso, Moreno y Sánchez, 2004: 5), de un modo similar al andrógino.

Si en la androginia de Virginia Woolf veíamos la posibilidad de liberación femenina mediante la fusión con el sexo opuesto, Haraway toma la tecnología como aliada para encontrar un espacio político propio: «no se trata de una dimensión alienante para el humano, sino salvadora a través de la fusión con lo que no es él, con la máquina» (Aguilar, 2008: 90) ) $^{51}$ la androginia de Woolf pretendía liberar la creación literaria del sexo y plantear una política de igualdad e independencia económicas; el ciborg sitúa el discurso feminista en un espacio propio, con el que pretende derribar, ya no solo las barreras de sexo o género, sino las de clase y raza: «de las relaciones cultura-naturaleza que Haraway considera dicotomías

\footnotetext{
50 No hablaremos aquí de ciberfeminismo, ya que la propia Haraway no se considera ciberfeminista; su propuesta ve simplemente en la tecnología un campo abierto a la deconstrucción de la identidad, la sexualidad y el género (Aguilar, 2008: 107). El ciberfeminismo bebe de la teoría de Haraway pero plantea en realidad el rechazo total a la identificación de la mujer con la naturaleza y la utilización de las tecnologías como nuevo espacio de lucha feminista, postura esta de algunos grupos de webgrrls como las Guerrilla Girls (Aguilar, 2008: 109 y 110). V. también García, Moreno y Sánchez (2004).

${ }^{51}$ La radicalización de esta teoría la encontramos en el transhumanismo, una propuesta que busca, al modo de las películas de ciencia ficción, la fusión de lo humano con la tecnología para dar lugar a un ciborg real, donde solo sobreviva la mente: «La posición transhumanista, antihumanista por excelencia, de las relaciones hombre-naturaleza-tecnología elimina el segundo término y, de los otros dos, decide que la tecnología cautive al humano en aras de una existencia inmaterial que elide de plano cualquier responsabilidad de dominación y la asume» (Aguilar, 2008: 90). V. al respecto Dvorsky, George y Hughes, James (2008): «Postgenderism: Beyond the Gender Binary», IEET, 3; donde se busca la posibilidad de una experiencia andrógina a través de la selección genética. V. también Aguilar (2008: 65 y ss.). Frente a estas teorías, el feminismo de Haraway partirá de la desestructuración de las dicotomías dentro de una tradición postestructuralista y de unos objetivos humanistas (Aguilar, 2008: 91).
} 
Ana Sánchez Anguix. Andróginos y ciborgs...

obsoletas o analíticas del pensamiento occidental caduco, extrae una idea de ser humano que ensambla ambos polos a través de los avances de la tecnología cibernética y biológica» (Aguilar, 2008: 96) ${ }^{52}$.

Para Haraway, el ciborg deviene la metáfora de liberación feminista durante la era tecnológica; a través de una simbiosis con lo no humano, se pretende crear «identidades fluidas», paralelas a la del andrógino, donde lo androide no suponga un «determinismo bio-lógico», sino una «puerta abierta por la que escapar de nuestra condición humana, oprimida, mediatizada, explotada» (Aguilar, 2008: 16).

\subsection{Ciborgs: replicantes en busca de una identidad}

Hay una fantasía flotando, tenaz, en nuestra cultura desde hace siglos: la de que el hombre creó a la mujer. Y otra aún más osada, que procede de ella: la de que el hombre produce criaturas femeni-nas más hermosas y mejores que las mujeres, con las que puede sustituir a éstas con ventaja para lo bueno y para lo malo, para el amor sublime y para la paliza mortal

Pilar Pedraza

Si el cuerpo es una materia sobre la que se escribe y se ejerce poder a través del len-guaje y otros actos (Butler, 2002: 110 y 111), el código genético que constituye los cuerpos se siente como otro mecanismo de control (Aguilar, 2008: 10, 54). El cuerpo se halla inmerso en la tecnología, que vuelve obsoleta las categorías de género y de lo humano (Aguilar, 2008: 9-11). La tecnología es una herramienta de liberación y de opresión: si el feminismo de Haraway toma como figura la del ciborg para hacer estallar las categorías que controlan el cuerpo y la identidad de género, la ingeniería artificial y la genética se dirigen en un principio hacia el panóptico total, donde la vigilancia la ejerce el cuerpo sobre

\footnotetext{
$52 \mathrm{Si}$ acudimos al ensayo de Woolf, podremos igualmente establecer una comparación entre ambas autoras: las dos pretenden, a su manera, fundir dos polos y acabar con los dualismos de género («Debe consumarse una boda entre elementos opuestos», 141; «ni siquiera en Cambridge, donde saben tanto poner a la gente en categorías (...)», 142, «al madurar, la gente deja de creer en bandos», 143); asimismo, encontramos tanto en el texto de Woolf como en el de Haraway una ironía mordaz: «he copiado para vuestro beneficio el consejo que os da el crítico de que reconozcáis valientemente las limitaciones de vuestro sexo» (Woolf, 2001: 150); «en el centro de mi irónica fe, mi blasfemia es la imagen del ciborg» (Haraway, 1995: 1).
} 
Ana Sánchez Anguix. Andróginos y ciborgs...

sí mismo (Aguilar, 2008: 43) ${ }^{53}$. La apropiación de la escritura del ciborg no será una simple toma de poder, sino la tarea «de empuñar las herramientas que marcan el mundo y que las marcó como otredad» ${ }^{54}$; el ciborg plantea nuevas estrategias de comunicación, la proliferación de códigos que alteran las dicotomías establecidas en la cultura occidental (Haraway, 1995: 30 y 31$)^{55}$.

El ciborg se apropia, como la figura del andrógino, de lo abyecto. Haraway (1995: 1) apunta a un ser donde lo orgánico y lo natural se funden para dar lugar a una metáfora, a un discurso nuevo, que escapa del control de los cuerpos; «a finales del siglo XX (...) todos somos quimeras, híbridos teorizados y fabricados de máquina y organismo», de ahí ese ser de ciencia ficción irreverente y monstruoso que se enmarca dentro de una utopía sin géneros (Haraway, 1995: 1y 2). El ciborg es una ironía que estalla, rompe y a un tiempo se nutre del cine y de la literatura donde abundan los autómatas (Haraway, 1995: 3 y 4) ${ }^{56}$. La apropiación en el feminismo de una figura (el autómata, el androide) que encarna un cuerpo artificial creado para la complacencia sexual masculina constituye uno de los «mitos más poderosos de resistencia y reacoplamiento» (Haraway, 1995: 7).

Pedraza (1998: 21) advierte en este sentido que las autómatas no son sino «una imagen ideal de feminidad» creada por el hombre en base a sus propios deseos, una imagen que surge con las vanguardias

\footnotetext{
53 Para Haraway, el ciborg es una imagen poderosa en tanto que no entra en el panóptico de Foucault, sino que «si-mula políticas», crea un espacio discursivo propio y rompe con las dicotomías occidentales humano/animal, naturaleza/cultura, público/privado, mente/cuerpo, hombre/mujer; con la figura del ciborg, las mujeres retoman sus cuerpos (Haraway, 1995: 16 y 17). Estos dualismos han cristalizado precisamente la dominación de aquello que tradicionalmente ha constituido lo otro: las mujeres, los negros, la naturaleza, los trabajadores, los animales; la fusión de contrarios, ya encarnada en el ciborg, ya en el andrógino, supone en el lenguaje la recuperación de su identidad (Haraway, 1995: 32). El ciborg como un espacio político propio en el feminismo constituirá, además, el opuesto a la desorientación del sujeto en la era de la información (Aguilar, 2008: 56 y 57).

54 Para Haraway, esta nueva resistencia política y discursiva tiene su referente en los textos de mujeres afroamerica-nas, donde la escritura equivalía a identidad (Aguilar, 2008: 24).

55 Haraway habla del tecnobable, un conjunto de lenguajes contrarios al de la dominación que actúan, no sobre los cuerpos, sino sobre los propios discursos (Aguilar, 2008: 67; en nota al pie). El lenguaje deja de ser una forma de opresión para pasar a constituir una subversión (Aguilar, 2008: 103). No solo el ciborg sino también el andrógino crean espacios de indiferenciación, un lugar de resistencia a los discursos hegemónicos en el que el yo acaba por disolverse (Cróquer, 2001: 98 y 99) (v. nota 41).

${ }^{56}$ Desde Frankenstein y los cuentos de Hoffmann hasta los androides de la posmodernidad hay toda una evolución: la muñeca o el autómata del XIX son máquinas que crean inquietud y terror, por tratarse de seres totalmente artificiales y siniestros; los robots y ciborgs del XX y del XXI, estos parcialmente humanos frente a aquellos (Merás, 2014: 8), han alcanzado tal complejidad que han pasado a representar el dilema filosófico de poner límites a lo hu-mano: ¿quiénes son los autómatas, ellos o nosotros? Es precisamente esa cuestión la que abrirá otros interrogantes en el feminismo: el ciborg representará la superación de las fronteras entre lo humano y lo no humano (animales y máquinas), la ruptura de clases, razas, géneros y hasta del mismo control del espacio: «La maquinaria moderna es un advenedizo dios irreverente que se burla de la ubicuidad y de la espiritualidad del Padre» (Haraway, 1995: 4-6).
} 
Ana Sánchez Anguix. Andróginos y ciborgs...

como reflejo demonizado del miedo a la mujer y a la tecnología en el expresionismo, o como vehículo del odio futurista a la mujer madre, frente al amor fascista por el padre y las máquinas (Pedraza, 1998: 192 y 193), y que se ha ha venido perpetuando desde los años setenta, época que coincide con el auge de los feminismos, hasta hoy (Pedraza, 1998: 25). Hay una tensión entre este nuevo feminismo y ese ideal consagrado de la mujer como muñeca o robot que trata de asentar el concepto de femineidad (Aguilar, 2008: 111): «no existe nada en el hecho de ser "mujer" que una de manera natural a las mujeres» (Haraway, 1995: 7); en el ciborg, las máquinas «no nos dominan, no nos amenazan. Somos responsables de los límites, somos ellas» (Haraway, 1995: 36).

En el cine de ciencia ficción, el control por parte de los ciborgs de su propia sexualidad determinará su carácter subversivo (ligado a la teoría de Haraway) o su docilidad (rasgo que señala Pedraza para el cuerpo femenino artificial) (Merás, 2014: 17 y 30). De este modo, encontramos en Pris y Zhora, replicantes en la película Blade Runner (1982), la figura de un ciborg que se adueña de su propio cuerpo y sexualidad y que subvierte por tanto la norma que rige su mundo, ya que fueron creadas precisamente para la explotación sexual (Merás, 2014: 15); su caracterización física ya nos advierte de la fortaleza y rebeldía de estas replicantes, frente a Rachael, mujer sumisa y sentimental (Pedraza, 1998: 250 y 251). Las esposas de Stepford (1975), en cambio, plantea un tratamiento más complejo de los ciborgs femeninos: si el film versa sobre la existencia de una ciudad donde las mujeres son asesinadas y sustituidas por máquinas serviciales con sus maridos, la óptica terrorífica mediante la que se enfoca el argumento supone una crítica del miedo patriarcal a la liberación de la mujer ${ }^{57}$.

En Las esposas de Stepford, Joana Eberhart, una promesa de la fotografía, y su amiga Bobbie Markowe, una mujer moderna que se burla de sus recatadas vecinas, acabaran convirtiéndose en unas de esas amas de casa de los años cincuenta que se mueren si no consiguen una receta o quieren «sentirse una mujer y mantener la casa limpia», integrándose, a través de la tecnología, en una concepción del cuerpo instrumentalizada (Haraway, 1995: 22 y 23), tanto para el placer sexual como para una economía del trabajo casero lite-ral (v. Haraway, 1995: 20).

En EVA (2011), lo que se plantea es la creación de un androide con libertad de pensamiento y sentimientos, esto es, un ciborg, en principio, libre y, por tanto, sometido al error, un error que en los ciborgs no se perdona, y acaba, así, con la muerte (Merás, 2014: 21). Lo interesante de esta película es

\footnotetext{
${ }^{57}$ Merás (2014: 22-26) recuerda las diferencias entre esta primera adaptación cinematográfica de la novela de Ira Levin y el remake de 2004, donde lo humorístico prima sobre lo terrorífico y la creación de autómatas es llevada a cabo, no por un hombre, sino por una neurocirujana que añora la familia tradicional, final más ambiguo que el primero, donde la protagonista acaba siendo sustituida por su doble autómata; la diferencia fundamental entre una y otra versión, pues, estriba en la consolidación de los feminismos.
} 
que, aunque el tema es la creación de niños robot, el hecho de asignarles uno u otro sexo condicionará su forma de ser, de modo que las niñas son más maduras, sensibles y guapas, pero también más perversas, asociando, de nuevo, la maldad del organismo cibernético con una maldad exclusivamente femenina (Merás, 2014: 20). El film, pues, cae en el estereotipo de la mujer autómata.

De nuevo, la mujer-máquina, el ciborg que aquí estudiamos, nos sitúa en una ambivalencia que, bien se resuelve en una adhesión al estereotipo de la autómata, bien se convierte en una imagen y lenguaje transgresores.

\section{Andróginos, ciborgs: monstruos queer}

Ya hemos visto cómo las imágenes del andrógino y del ciborg se apropian de lo abyecto para hacer tambalear las categorías que determinan la identidad sexual del sujeto, lo que refleja una evolución del feminismo deconstructivista hacia las teorías queer $^{58}$, que ponen en cuestión cualquier intento de definición genérica o sexual de los individuos y optan por identidades fluidas, ambiguas, donde se produzca una desidentificación con respecto a aquellas dicotomías del heteropatriarcado (Butler, 2002: 21). Lo queer es la redefinición de una orientación e identidad sexual patologizadas como la posibilidad de rescatar «ciertos cuerpos en los límites de las ontologías accesibles» (Butler, 2002: 315): lo abyecto, como el cuerpo del andrógino o del ciborg se transforma en un lugar de resistencia (Butler, 2002: 325).

En la ambigüedad del andrógino, se encuentra la posibilidad de desplazar los deseos construidos a partir de los pares masculino/femenino (Butler, 2007: 96); así, en $X X Y$, la rela-ción entre Álex y Álvaro

\footnotetext{
58 A propósito de la relación entre los feminismos y las teorías queer, Butler afirma que la presuposición de la existencia del sexo en algunos trabajos feministas ha acarreado la consolidación de una dualidad sexual que con frecuencia ha excluido identidades alejadas de la norma y sí planteadas en las teorías queer (Butler: 2007: 8), lo cual resulta curioso para estudiar cómo estas últimas han partido de los feminismos, pero también como estos pueden nutrirse a un tiempo de ideas nuevas presentes en lo queer.
} 
Ana Sánchez Anguix. Andróginos y ciborgs...

plantea una ruptura con lo dicotómico ${ }^{59}$ : cuando este pregunta a aquel/aquella si le gustan los hombres o las mujeres, habiendo descubierto su anatomía, la respuesta no se halla en la bisexualidad, sino en un deseo que irá más allá; Álex no puede ser lesbiana, gay o heterosexual porque su cuerpo cuestiona per se el binarismo sexual hombre/mujer; el discurso es un «acto corporal con consecuencias lingüísticas específicas» (Butler, 2007: 31) ${ }^{60}$, y la figura de la/el intersexualidad en la literatura y el cine supone la ruptura de la dualidad sexual: la sexualidad de Álex quiebra la heterosexualidad hegemónica creada en torno al falo (Butler, 2007: 93).

Otro ejemplo de androginia, más ligada a lo queer, la encontramos en La traición de Rita Hayworth, novela de Manuel Puig en que se produce la desidentificación sexual ${ }^{61}$ de un niño -Toto- con los modelos masculinos (su padre) y la identificación con los femeninos (su madre, pero en especial las divas de Hollywood); de este modo, el protagonista se construye a partir de una ambigüedad sexual en paralelo con las referencias al cine de masas, que crea figuras masculinas y femeninas hipersexualizadas (Ferrero, 2011: 301), y con discursos igualmente alejados de lo hegemónico, como el chisme, género que aglutina voces que escapan de lo legítimo (Ferrero, 2011:304) ${ }^{62}$.

El momento clave se encuentra al inicio de la novela, cuando Berto, el padre de Toto, deja de acompañar definitivamente a su hijo y a su esposa al cine: Toto entonces asimilará el papel de Hayworth en Sangre y arena, en una escena en que los roles de género están cambiados y la mujer traiciona al

${ }^{59}$ Butler (2002: 334-336) habla de una conceptualización de la sexualidad según el género con que el individuo se identifica; a partir de aquí se entiende el heterosexismo que subyace en realidad a la pregunta de Álvaro: como el intersexual no es ni hombre ni mujer, al amigo de Álex le resulta difícil esclarecer su orientación sexual. La película, finalmente, se decanta por la ambigüedad, tanto en la identidad sexual como en el deseo, y prescinde de cualquier etiqueta existente en el heteropatriarcado. Pero no solo se plantea esta cuestión en el personaje de Álex: el padre de Álvaro también cuestiona la hombría de su hijo en base a ciertas actitudes consideradas masculinas, como beber alcohol. El final de la película, en este sentido, también deja en interrogante el futuro de Álvaro, que ha des-cubierto su homosexualidad y deberá enfrentarse a un entorno homófobo. Es aquí donde los feminismos pueden enriquecerse de las teorías queer: «debe ser posible afirmar una serie de relaciones no causales y no reductoras entre el género y la sexualidad, no sólo para asociar el feminismo con la teoría queer, como podrán asociarse empre-sas separadas, sino para establecer su interrelación constitutiva» (Butler, 2002: 336 y 337).

60 «(...) el texto plantea cómo las prácticas sexuales no normativas cuestionan la estabilidad del género como categoría de análisis. ¿Cómo ciertas prácticas sexuales exigen la pregunta: qué es una mujer, que es un hombre?» (Butler, 2007: 12).

${ }^{61}$ Ya en el título, se observa una ambigüedad que torna a la figura de la diva en sujeto y objeto de la traición, que no es sino esa desidentificación y la apertura a múltiples posibilidades de redefinición sexual del deseo y de la identidad (Vivancos, 2006: 634).

${ }^{62}$ Ferrero (2011: 302-321) señala las semejanzas entre las técnicas narrativas de Gorodischer y Puig, la primera adscrita a un proyecto feminista, el segundo, en lo que más tarde se conocería como teoría queer: ambos autores recurren a lo oral como discurso ilegítimo para desarticular lo hegemónico y construir una política disidente y de la liberación sexual. 
Ana Sánchez Anguix. Andróginos y ciborgs...

hombre (Vivancos, 2006: 637) ${ }^{63}$. La desidentificación recibe una lectura queer porque supone una resistencia frente a las categorías que asignan un comportamiento y una sexualidad según el sexo (Vivancos, 2006: 639). La figura de la diva posee una ambigüedad que le permite envolverse en un halo de misterio y poseer belleza y maldad, dos rasgos que habían aparecido en la tradición como contrarios (Vivancos, 2006: 640); esa ambigüedad, a nuestro juicio, la comparte con el andrógino (Toto), que rechazará en este caso el rol masculino del padre para identificarse con aquel de la madre y de la diva del cine. La traición consiste, además, en la ruptura de un acto performativo (Vivancos, 2006: 641) ${ }^{64}$.

En las teorías queer, la identidad sexual no es una decisión personal, sino la obligación de citar una norma: la performatividad del género se convierte a propósito en una teatralización que resquebraja las estrechas posibilidades sexuales del heteropatriarcado y ataca las técnicas de abyección del propio cuerpo (Butler, 2002: 326). Es lo que sucede también en el travestismo. En La traición de Rita Hayworth, algunos pasajes se encargan de mostrar la ambigüedad sexual de Toto frente a los roles de género con los que empieza a entrar en con-tacto: se trata, por ejemplo, de sus juegos con muñecas o la separación de los baños por se-xos: «su inocencia lo coloca en un estado de creación, de fluidez, que continuará en el niño más adelante planteando una resistencia a estas normas» (Vivancos, 2006: 645 y 646).

Por otro lado, ya vimos cómo en Orlando el travestismo y el cambio de sexo suponen la puesta en escena de un deseo que desestructura la concepción del amor heterosexual y de los géneros tradicionales. El género en la novela de Woolf funciona, pues, como un acto performativo, de un modo similar a como lo concebiría Butler (Clio, 2012: 2). En los roman-ces de Orlando con la princesa rusa Sasha y la archiduquesa/el archiduque Harriette/Harry, Woolf intenta configurar un amor andrógino: la primera viste con ropas masculinas y seme-ja, en sus actitudes y su propia apariencia física, un hombre; la segunda/el segundo se aproxima a Orlando como una mujer para ser, finalmente, un hombre (ib.). Clio

\footnotetext{
${ }^{63}$ La identificación con una figura femenina, sin embargo, se produce también en el papel de María Espinosa, es-posa del torero en Sangre y arena; Vivancos (2006: 639) afirma que Toto, como María, es un mero espectador de la vida en Coronel Vallejos y expresa mientras tanto su admiración por su padre (Juan Gallardo); cuando este lo traiciona, rechazando el mundo del cine (el suyo y el de su madre, al fin y al cabo), Toto dejará de identificarse con Berto.

${ }^{64}$ A raíz de la lectura de Hueso (2012), podemos plantearnos si La traición de Rita Hayworth podría adscribirse a la estética camp, muy ligada a las políticas queer. Se trata en ambos casos de la burla de los dualismos sexuales y su superación no solo en el terreno individual, sino también en el cultural, ya que tanto las obras camp como La traición de Rita Hayworth absorben lo kitsch y la cultura de masas para la parodia (Hueso, 2012: 14). Asimismo, es frecuente en la estética camp la imitación de las divas de Hollywood «tanto en la construcción de identidades de género (...) como en el recurso de ciertos films que resultan fundamentales para comprender la lógica de estos relatos» (Hueso, 2012: 15), lo que ocurre con Toto y la figura de Rita Hayworth en la película Sangre y arena. También parece encajar aquí la imagen del andrógino: «el Camp latinoamericano es por excelencia el terreno de la ambigüedad» (Hueso, 2012: 252; la cursiva es nuestra).
} 
Ana Sánchez Anguix. Andróginos y ciborgs...

(2012: 2-5) compara en este sentido el travestismo del/de la protagonista con el drag queen, ya que a través del travestismo y el cambio de sexo se pretende caricaturizar los roles de género convencionales, los cuales contrastan con la ambigüedad en el matrimonio -práctica burguesa a la que debía someterse cualquier mujer en época victoriana- con Shelmerdine y que devienen una verdadera función teatral.

En cuanto a la figura del ciborg, ambas teorías -la queer y la de Haraway- proponen la eliminación de la dualidad del género, una mediante la desidentificación, otra, con la fusión entre los dos polos de una dicotomía (Aguilar, 2008: 112). Pero son muchas las ocasiones en que lo queer y la imagen del ciborg se entrelazan, sobre todo en las performances que tratan de poner en escena el control sobre la sexualidad o se sirven de las nuevas tecnologías para ridiculizar o criticar las identidades sexuales normalizadas ${ }^{65}$.

\section{Conclusiones}

Hemos visto cómo la representación de los cuerpos abyectos en la literatura y cine contemporáneos se convierte en una acción reivindicativa para aquellas identidades y sexualidades excluidas de lo considerado heteronorma. Hemos intentando ofrecer una visión panorámica de la cuestión, no solo comparando tres literaturas distintas (la británica, la latinoamericana, la española), sino también abordándolo desde dos puntos de vista complementarios: el feminista y el queer. Así, se ha partido de los presupuestos feministas para analizar la androginia y el ciborg hasta llegar al último apartado, donde intentamos sintetizar los fundamentos de la teoría queer.

Pero, si se mira atrás, se podrá comprobar que se han tratado estas dos perspectivas y estos dos monstruos simultáneamente, que desde la androginia de Woolf se ha podido esbozar el ciborg de Haraway, o que desde Butler, Lauretis y otras comienza a difuminarse la dualidad que juega en la construcción del deseo y de la subjetividad. En este sentido, cabe insistir en que tanto el andrógino como el ciborg son dos metáforas, y forman parte de un lenguaje transgresor que intenta romper dicotomías de sexo, de clase, de raza o incluso de lo humano.

\footnotetext{
${ }^{65}$ De este modo, encontramos performances queer como Akelarre ciborg, donde se une la tecnología al tema de la brujería y de los aquelarres, imagen que funciona como espacio de reunión de identidades subversivas (v. Solá, y Ortuño, 2012); también Magia aumentada incluye las tecnologías hápticas en relación con la construcción de las sexualidades, poniendo en escena el funcionamiento de la biopolítica según Foucault (v. Iglesias, 2013). Fuera del terreno de lo queer, pero no por ello desligado de él, encontramos Homogenneo, una performance realizada en el Teatro Inestable (Valencia) que trata de evidenciar la homogeneización de las identidades, abarcando, no solo el género, sino también la exclusión social de individuos que quedan fuera del patrón de comportamiento de una sociedad consumista; en este caso, la tecnología pasa a formar parte del cuerpo, simbolismo que se encuentra en las ropas de la protagonista.
} 
El andrógino y el ciborg perfilan sus figuras entre la luz y la oscuridad: los cuerpos de Orlando, de Álex, de Adrián/Adriana semiocultos en las sombras, ocultan su abyección; ¿es el andrógino hombre, o mujer? ¿Es ambos? ¿O no es ninguno? ¿Es el ciborg humano o máquina? ¿O es una máquina con algo más de humanidad? ¿Qué seres conforman la naturaleza, el orden? ¿Dónde se ubica el andrógino, si el ser humano es descrito con solo uno de los dos sexos? ¿Y dónde, el ciborg, producto de la nueva era tecnológica? Andróginos y ciborgs no solo devienen una metáfora contra las dicotomías de género, raza y clase, sino que plantean, asimismo, el modo en que el individuo se relaciona con la naturaleza. 
Ana Sánchez Anguix. Andróginos y ciborgs...

\section{Bibliografía citada}

Aguilar García, Teresa (2008). Ontología ciborg. El cuerpo en la nueva sociedad tecnológica. Barcelona: Editorial Gedisa.

Alcoff, Linda. "Feminismo cultural vs. Post-estructuralismo: la crisis de identidad de la teoría feminista". Revista Debats 76 (2002): 18-41.

Barrera López, Begoña. "Personificación e iconografía de la 'mujer moderna'. Sus protagonistas de principios del siglo XX en España”. Trocadero 26 (2014): 221-240.

Bartra Muria, Eli. "El cos de dona com a eix de la vida i la pintura de Frida Kahlo". Revista d'Estudis Feministes 5 (1993): 75-84.

Butler, Judith (2002). Cuerpos que importan: sobre los límites materiales y discursivos del sexo". Buenos Aires: Paidós.

Butler, Judith (2007). El género en disputa. El feminismo y la subversión de la identidad. Barcelona: Paidós.

Clark, Zoila. “Our Monstrous Humanimality in Lucía Puenzo's XXY and The Fish Child", Hispanet Journal, 5 (2012).

Clio Kao, Pei-Wen. "Queer Love in Orlando and Chu's Notes of a Desolate Man", CLCWeb: Comparative Literature and Culture, vol. 14, 1 (2012).

Cróquer Pedrón, Eleonora (2001). “'Otro modo que ser’: la escritura como responsabilidad”. Mattalía, Sonia y Girona, Nuria (edas.) Aun y más allá: mujeres y discursos. Caracas: Ediciones Excultura: 95-104.

De Lauretis, Teresa (1989). “La tecnología del género”. Technologies of Gender. Essays on Theory, Film and Fiction: $1-30$.

Ferrero, A. M. (2011)._Poéticas de la hipérbole: Las obras de Angélica Gorodischer y Tununa Mercado. La Plata: Universidad Nacional de La Plata, Facultad de Humanidades y Ciencias de la Educación.

Ferrús, Beatriz (2001). "Monja y Alférez o El binomio imposible”. Mattalía, Sonia y Girona, Nuria (edas.) Aun y más allá: mujeres y discursos. Caracas: Ediciones Excultura: 45-50. 
Ana Sánchez Anguix. Andróginos y ciborgs...

Fuster García, Francisco. "Feminismo y teoría política en Virginia Woolf: lectura de Una habitación propia desde el pensamiento de la diferencia sexual". Lectora: revista de dones i textualitat, 16 (2010): 211-227.

García Manso, Almudena; Moreno Díaz, Pilar y Sánchez Allende, Jesús. "Las nuevas identidades de género en el marco del siglo XXI: del ciborg a las identidades queer". Revista de Antropología Cultural4 (2004).

Gascón-Vera, Elena. "To be or not to be: la ansiedad de la androginia en Virginia Woolf". Clepsydra: revista de estudios de género y teoría feminista 1 (2002): 99-110.

Girona, Nuria (2008). Rituales de la verdad. Mujeres y discursos en América Latina. París/México: Associaton pour le Développement des Etudes Hispaniques en Limousin.

Gorodischer, Angélica. Kalpa Imperial. Barcelona: Gigamesh.

Haraway, Donna (1995). Manifiesto para Cyborgs: ciencia, tecnología y feminismo socialista a finales del siglo XX. València: Universitat de València, Centro de Semiótica y Teoría del Espectáculo.

Hueso Fibla, Silvia (2012). "Ya no estás a mi lado, corazón": Estética Camp en América Latina. València: Universitat de València, Facultad de Filología, Departamento de Filología Española.

Huyssen, Andreas (1986). "The Vamp and the Machine: Fritz Lang's Metropolis". After the Great Divide: Modernism, mass culture, Postmodernism. Bloomington: Indiana University Press: 65-81.

Iglesias López, Beka. “Tecnologías hápticas, transfeminismo(s) y magia aumentada”. Teknokultura. Revista de cultura digital y movimientos sociales vol. 10, 3 (2013): 747-758.

López Rodríguez, Rosana. "Del feminismo al deconstructivismo de género: la narrativa de Angélica Gorodischer en los'30 y los '90”. Cuadernos del CILHA 11 (2009): 54-67.

Lojo Rodríguez, Laura María. "Virginia Woolf y la autobiografía femenina”. Actas XXVIII Congreso Internacional AEDEAN (2004). València: Universitat de València, Departament de Filologia Anglesa i Alemanya.

Mattalía, Sonia (2003). Máscaras suele vestir. Pasión y revuelta: escritura de mujeres en América Latina. Madrid: Iberoamericana. 
Ana Sánchez Anguix. Andróginos y ciborgs...

Merás, Lidia. "Replicantes o sumisas: el cyborg femenino desde Blade Runner". Sesión no numerada: Revista de letras y ficción audiovisual 4 (2014): 7-33.

Ocampo, Silvina (1999). “Las vestiduras peligrosas”. Cuentos completos vol. 2. Buenos Aires: Emecé.

Osborne, Raquel (2005). "Debates en torno al feminismo cultural”. Amorós, Celia y De Miguel, Ana (edas.) Teoría feminista: de la Ilustración a la globalización II. Del feminismo liberal a la posmodernidad. Madrid: Minerva: 211-252.

Pedraza, Pilar (1984). Las joyas de la serpiente. Valencia: Fernando Torres.

Pedraza, Pilar (1998). Máquinas de amar. Madrid: Valdemar.

Peidro, Santiago. "Dos casos de intersexualidad en el cine argentino". Revista Latinoamericana 14 (2013): 66-90.

Pérez, Águeda. "La identidad genérica como sitio de conflicto en dos cuentos de Silvina Ocampo", Ciberletras, 11.

Peris, Jaume (2001): “Corporalidad y abyección en las crónicas de Pedro Lemebel”. Mattalía, Sonia y Girona, Nuria (edas.) Aun y más alláa: mujeres y discursos. Caracas: Ediciones Excultura: 233-238.

Platón (2012). El banquete (traducción y notas de Fernando García Romero,). Madrid: Alianza Editorial.

Posada Kubissa, Luisa (2005). "El pensamiento de la diferencia sexual: el feminismo italiano. Luisa Muraro y el orden simbólico de la madre”. Amorós, Celia y De Miguel, Ana (edas.) Teoría feminista: de la Ilustración a la globalización II. Del feminismo liberal a la posmodernidad. Madrid: Minerva: 253-288.

Preciado, Beatriz. "El feminismo no es un humanismo" Parole de queer (2014b).

Puig, Manuel (2009). La traición de Rita Hayworth. Barcelona: Seix Barral.

Robles Moreno, Lola (2008). "Las otras: feminismo, teoría queer y escritoras de literatura fantástica”. López Pellisa, Teresa y Ángel Moreno, Fernando (eds.): Ensayos sobre ciencia ficción y literatura fantástica. Madrid: Asociación Cultural Xatafi/Universidad Carlos III: 615-627.

Rognstad, Marte (2012). The Representation of Gender in Virginia's Woolf Orlando and Jeffrey Eugenide's Middlesex. Universitete i Oslo. 
Ana Sánchez Anguix. Andróginos y ciborgs...

Ruiz Gisbert, Rosa. “Maruja Mallo y la Generación del 27”. Isla de Arriarán XXVIII (2006): 223-240.

Solá García, Miriam y Ortuño, Pedro. “Akelarre ciborg”, Arte y políticas de identidad vol. 6 (2012): 291-295.

Solorza, Paola Susana. "Belleza y abyección: la representación del cuerpo femenino en la narrativa de Silvina Ocampo". Revista Espacios 42 (2009): 108-115.

Todorov, Tzvetan (1981). Introducción a la literatura fantástica. México D.F.: PREMIA.

Vásquez Rodríguez, Gilberto (1998). "Identidad y tácticas de androginia en el imaginario literario hispanoamericano". Miradas y voces de Fin de Siglo. Actas del VIII Congreso Internacional de la asociación española de semiótica: 973-981.

Vásquez Rodríguez, Gilberto (2001): "Erotismo y androginia en la narrativa española contemporánea”. Literatura y sociedad, el papel de la literatura en el siglo XX: I Congreso Nacional de Literatura y Sociedad. A Coruña: Universidade da Coruña: 177-194.

Vivancos Pérez, Ricardo: "Una lectura queer de Manuel Puig: Blood and Sand en La traición de Rita Hayworth". Revista Iberoamericana vol. LXXII, 215-216 (2006): 633-650.

VNS Matrix: “Manifiesto de la zorra mutante” Estudios Online (trad. de Carolina Díaz Soto).

Woolf, Virginia (2005). Una habitación propia. Barcelona: Editorial Seix Barral.

Woolf, Virginia (1995). Orlando (trad. de Jorge Luis Borges). Salvat Ediciones.

Wright, Elizabeth. "Re-evaluating Woolf”s Androgynous Mind”. Postgraduate English 14 (2006).

\section{Filmografía citada}

Forbes, Bryan (1975). The Stepford Wives. Estados Unidos: Scherick.

Maíllo, Kike (2011). EVA. España: Casamitjana, Roig y otros.

Preciado, Beatriz. "Beatriz Preciado en conversación con Marianne Ponsford”. Hay Festival 2014 (2014a).

Puenzo, Lucía (2007). XXY. Argentina: Puenzo y Morales. 
Scott, Ridley (1982). Blade Runner. Estados Unidos: Michael Deeley.

Villar, Samanta. “Entre dos sexos” Conexión Samanta (2015). 